\title{
Engineering the Organization: Is USACE Doing it Right?
}

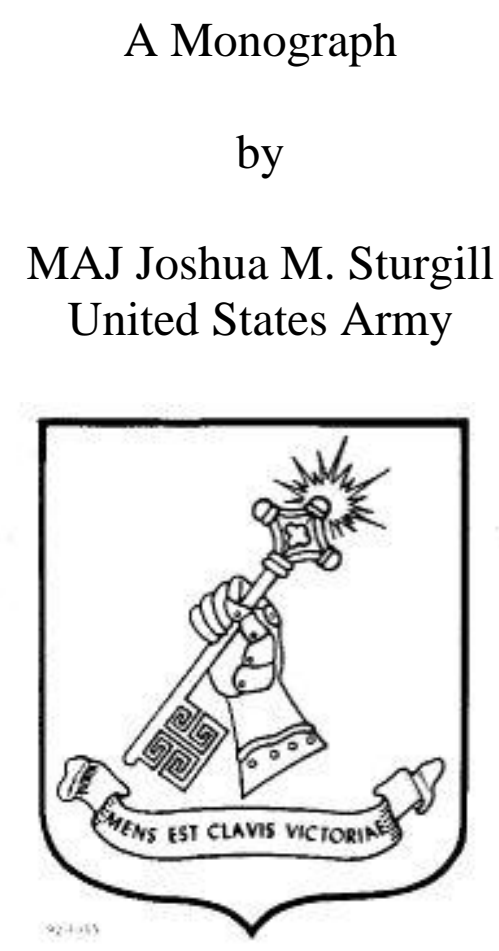

School of Advanced Military Studies

United States Army Command and General Staff College

Fort Leavenworth, Kansas

2015-01 


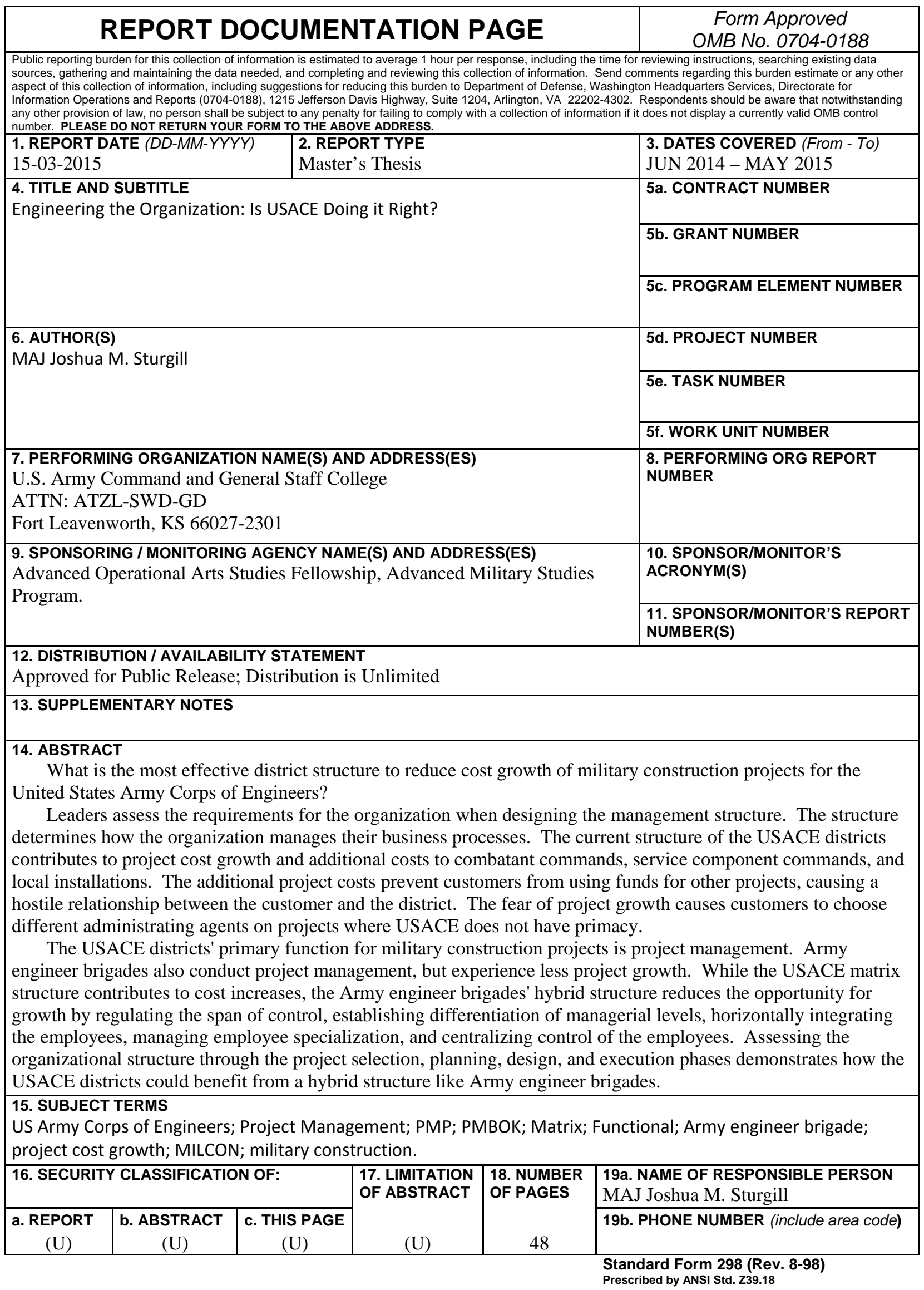




\section{Monograph Approval Page}

Name of Candidate: $\quad$ MAJ Joshua M. Sturgill

Monograph Title: $\quad$ Engineering the Organization: Is USACE Doing it Right?

Approved by:

Monograph Director

Gerald S. Gorman, PhD

, Seminar Leader

Michael D. Rayburn, COL

, Director, School of Advanced Military Studies

Henry A. Arnold III, COL

Accepted this 23rd day of May 2015 by:

Robert F. Baumann, PhD

, Director, Graduate Degree Programs

The opinions and conclusions expressed herein are those of the student author and do not necessarily represent the views of the US Army Command and General Staff College or any other governmental agency. (References to this study should include the foregoing statement.) 


\begin{abstract}
Engineering the Organization: Is USACE Doing it Right?, by Joshua M. Sturgill, 48 pages.

What is the most effective district structure to reduce cost growth of military construction projects for the United States Army Corps of Engineers?

Leaders assess the requirements for the organization when designing the management structure. The structure determines how the organization manages their business processes. The current structure of the USACE districts contributes to project cost growth and additional costs to combatant commands, service component commands, and local installations. The additional project costs prevent customers from using funds for other projects, causing a hostile relationship between the customer and the district. The fear of project growth causes customers to choose different administrating agents on projects where USACE does not have primacy.

The USACE districts' primary function for military construction projects is project management. Army engineer brigades also conduct project management, but experience less project growth. While the USACE matrix structure contributes to cost increases, the Army engineer brigades' hybrid structure reduces the opportunity for growth by regulating the span of control, establishing differentiation of managerial levels, horizontally integrating the employees, managing employee specialization, and centralizing control of the employees. Assessing the organizational structure through the project selection, planning, design, and execution phases demonstrates how the USACE districts could benefit from a hybrid structure like Army engineer brigades.
\end{abstract}




\section{Contents}

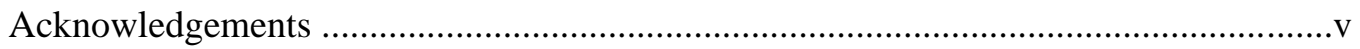

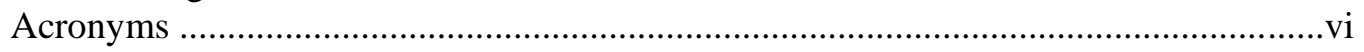

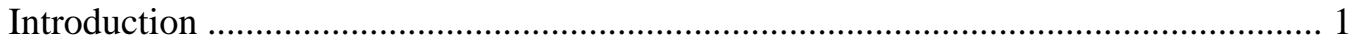

Chapter 1. Organizational Structures ..........................................................................

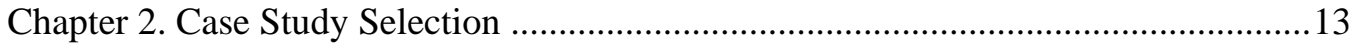

Chapter 3. Cost Control Procedures during the Selection and Design Phase .................23

Chapter 4. Cost Control Procedures during Construction ............................................. 36

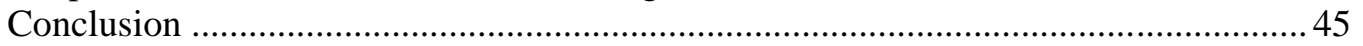




\section{Acknowledgements}

I am deeply grateful to the multiple people that made this monograph possible. First, my appreciation goes to my wife, without whom this would not have been possible. Her patience, understanding through long days, and caring for our baby girl at night so I could work ensured I had time to research. Regards go out to Lieutenant Colonel Michelle Garcia, Roberta Chrissy, Joanne Hensley, Leanne Layne, and Mark McKitrick for helping me start my research and find out my unknown, unknowns. A special thank you to Janet Yarnell, Rick Calloway, Paul DesRoches, Lieutenant Colonel Thomas Asbery, Lieutenant Colonel Aaron Dorf, Lieutenant Colonel Julian C. Smith, III, Major Rachael Honderd, Major Nathan Smith, and Major Joshua Long for providing a myriad of information including personnel numbers in the various USACE districts, project growth numbers, standard operating procedures, and methods for locating after action reviews for engineer brigade projects.

My gratitude also goes to Brigadier Generals Kent Savre and Jeffrey Milhorn. Your insight and continued mentorship allowed me to identify various issues and recognize the complexity of the problems faced when constructing an organization. Finally, to my monograph director, Dr. Scott Gorman, who ensured I always remembered my research question and focused on getting the answer. 


\section{Acronyms}

\begin{tabular}{|c|c|}
\hline AR & Army Regulation \\
\hline AFARS & Army Federal Acquisition Regulation Supplement \\
\hline DFARS & Defense Federal Acquisition Regulation Supplement \\
\hline $\mathrm{EP}$ & Engineer Pamphlet \\
\hline ER & Engineer Regulation \\
\hline FAR & Federal Acquisition Regulation \\
\hline FM & Field Manual \\
\hline MILCON & Military Construction \\
\hline $\mathrm{PM}$ & Project Manager \\
\hline $\mathrm{PMBOK}^{\circledR}$ & Project Management Book of Knowledge \\
\hline PMBP & Project Management Business Process \\
\hline PMI & Project Management Institute \\
\hline PMP & Project Management Professional \\
\hline RMS & Resident Management System \\
\hline SOP & Standard Operating Procedure; Standing Operating Procedure \\
\hline $\mathrm{TM}$ & Technical Manual \\
\hline UFC & Unified Facilities Criteria \\
\hline USACE & US Army Corps of Engineers \\
\hline
\end{tabular}




\section{Introduction}

Organizational excellence is impossible without individual excellence. And individual excellence today, especially in managerial and professional jobs, demands much more than technical competence. It demands a sophisticated type of social skill: a leadership skill that can mobilize people and accomplish important objectives despite dozens of obstacles; a skill that can pull people together for meaningful purposes despite the thousands of forces that push us apart; a skill that can keep our important corporations and public institutions from descending into a mediocrity characterized by bureaucratic infighting, parochial politics, and vicious power struggles.

\section{-- John P. Kotter, Power and Influence: Beyond Formal Authority}

The Fiscal Year 2015 budget requires the United States Army Corps of Engineers (USACE) to increase the efficiency of their management structure to save money. ${ }^{1}$ Congress appropriates funds for specific projects requested by combatant commands, who then contact the USACE to oversee the project from cradle to grave. The current budget situation in the United States leads many to believe a reduction in defense spending will result in less projects approved by Congress. Reducing USACE's contract administration expenses increases the amount of money organizations have for projects. This leads to the research question of this monograph: what is the most effective district structure to reduce cost growth of military construction projects for the USACE?

The hypothesis of this monograph is that the most effective structure to reduce cost growth of military construction projects is a hybrid organization, with functional managers at the central district office with regional self-contained units. The USACE is comprised of forty three districts divided between nine divisions. These districts are responsible for all navigable waterways in the United States (known as Civil Works), construction projects on military bases (known as Military Construction), and construction for multiple agencies in foreign countries

${ }^{1}$ US Office of Management and Budget, FY2015 Budget of the US Government (Washington, DC: US Government Printing Office, 2014), accessed August 20, 2014. http://www.whitehouse.gov/sites/default/files/omb/budget/fy2015/assets/budget.pdf. 
throughout Europe, Asia, and Africa. The districts have several hundred employees and can cover areas up to 700,000 square miles spread across multiple states. ${ }^{2}$ This monograph shows organizations this size are too big to use the functional organization framework and too bureaucratic to function as a pure matrix organization.

The research answers the question by analyzing the origins of the different types of organizational structures, determining the benefits and drawbacks of each organization type, and comparing a district structure to a US Army engineer brigade to show an opportunity for a potential reduction of cost growth on military construction projects. Determining an organizational structure that could reduce military construction project growth will allow USACE to streamline offices focused on military construction while increasing productivity in a time of tightening budgets across the United States Government.

Three aspects need consideration to test the validity of the hypothesis: the benefits and drawbacks of the types of organization structures, the current structure of districts and engineer brigades, and whether organizational structures provide opportunities for increased or decreased project cost growth. Research focused on organizational development and project management schools of thought provide the benefits and drawbacks of the different structures. An analysis of the districts' personnel operating rosters shows the existing structures of the USACE district, while US Army doctrine provides the structure of an engineer brigade. A review of engineer regulations and pamphlets issued by USACE Headquarters provide how districts structure to conduct operations, and standard operating procedures issued by three engineer brigades allow for a comparison between the organization types.

This monograph contains four chapters. The first chapter introduces the four most common organizational structures used today. To prevent confusion among the various theorists,

\footnotetext{
${ }^{2}$ For a history of the US Army Corps of Engineers see Engineer Pamphlet (EP) 360-1-21, The History of the US Army Corps of Engineers (Washington, DC: HQ, US Army Corps of Engineers, 1986).
} 
the paper uses the terms functional, self-contained units, matrix, and hybrid to describe the organization types. ${ }^{3}$ The chapter outlines that functional organizations contain stovepipes of specialists, self-contained units benefit from having all information under a single manager, and the matrix organization uses a project manager and functional managers to control projects. Finally, it describes the idea of a hybrid organization, one that takes aspects from other organizational types and combines them to achieve the best results.

Chapter Two documents how the organizations control cost growth on projects. It reviews the organizational structure of USACE districts commanded by colonels and provides insight into the USACE districts' cost growth problem. The chapter also evaluates the structure of active duty US Army engineer brigades as an example of a hybrid organization with functional advisors to the commander and self-contained organizations to develop projects and reduce cost growth.

Chapter Three compares how the USACE districts and Army engineer brigades control cost growth during the selection and design of projects. It describes how the organizations distribute the processes needed during this phase. Chapter Four reviews how the organizations monitor and control projects during construction with a focus on reducing the opportunities for project growth. The USACE districts' incorporates intricate processes during the construction phase to comply with the fiscal limits imposed by the government, while the US Army engineer brigades follow self-imposed rules to prevent cost growth during construction.

\footnotetext{
${ }^{3}$ John G. Maurer, foreword to Organization Charts: Structures of More Than 200 Businesses and Non-Profit Organizations, ed. by Judith M. Nixon (Detroit, MI: Gale Research Inc., 1992), ix.
} 


\section{Chapter 1}

\section{Organizational Structures}

Every organization chooses the aspects from theory they feel are most important to their business. As complexity theory suggests, there is no single solution for what makes a company great. Jim Collins proves this in his comparative study Good to Great, documenting what made companies perform three times better than the stock market for fifteen years preceded by fifteen years of mediocre returns. ${ }^{4}$ Collins showed it takes leadership, the right people in the right jobs, a defined objective, and the right culture. A leader must establish an organizational structure so the organization can get the right people and develop the company's objective. Managers rely on organizational designers to identify the best structure for their business based on several factors to accomplish the company's goal.

Organizational design theorists do not have a common language to describe organization types, resulting in similar concepts with different terminology. Jay R. Galbraith proposes leaders design the organization by considering the modes of lateral relations, self-contained units, slack resources, and vertical information systems. ${ }^{5}$ He does not correlate the modes to specific organizational structures, but these concepts loosely translate to the four structures Judith M. Nixon lays out in Organization Charts functional, self-contained units, matrix, and hybrid organizations. ${ }^{6}$

Mary Jo Hatch and Ann L. Cunliffe claim there are eight common dimensions leaders consider when creating organizations. To maintain consistency among theorists, the analysis

${ }^{4}$ Jim Collins, Good to Great: Why Some Companies Make the Leap... and Others Don't (New York, NY: HarperCollins Publishers Inc., 2001), 5-6.

${ }^{5}$ Jay R. Galbrath, Organization Design (Reading, MA: Addison-Wesley Publishing Company, 1977), 6.

${ }^{6}$ Maurer, foreword to Organization Charts, ix. 
focuses on the span of control, differentiation, integration, specialization, and centralization while leaving size, standardization, and formalization for further research. ${ }^{7}$

The organizational designers help determine span of control to ensure managers possess the ability to control their subordinates. They analyze the differentiation, or number of hierarchical levels and how employees integrate and communicate between levels. The leader determines if control is centralized or decentralized, and how that control spreads throughout the managerial staff. Finally, the leader and organizational designer determine the amount of specialization required to fulfill the company's objective. ${ }^{8}$

\section{Functional Organization}

Functional organizations epitomize classical design theory. The organization has a senior manager with subordinate managers for each of the specialized areas in the company. These subordinate managers have supervisors with team leaders. Each employee is subordinate to one team leader/supervisor with a hierarchical structure and little integration between sections.

Functional organizations have large administrative components because the branches do not conduct their own administrative tasks. The human resource section handles administrative tasks including payroll and personnel hiring actions. Managers from the other functional sections interact with the human resource section to resolve issues their employees encounter.

Top tier managers regulate the management levels by hiring intermediate managers and regulating the span of control. The senior levels of management focus solely on management while team leaders and supervisors address technical problems. The levels of hierarchy increase with the organization, while companies balance the risk of increasing span of control.

\footnotetext{
${ }^{7}$ Mary Joe Hatch and Ann L. Cunliffe, Organizational Theory, 2nd ed. (New York, NY: Oxford University Press, 2006), 106.

${ }^{8}$ Ibid.
} 
Supervisors at lower levels perform technical and administrative tasks so long as the span of control allows. The organization must hire more intermediate managers once team leaders begin to perform more administrative tasks than technical tasks.

Functional organizations are poorly integrated. Cross-departmental communication rarely occurs and managers resolve most issues. ${ }^{9}$ The functional nature of the organization leads to "over-the-fence" management, where one sections completes their work on a task then passes it to another section without coordination or supervision of the overall task. ${ }^{10}$

The specialization of functional areas increases the efficiency of each department through shared learning by specialists. Managers distribute lessons learned within their departments to prevent repeating mistakes within the function. This increased efficiency suffers from the law of diminishing returns, where increasing resources does not increase the return on investment at the same rate. ${ }^{11}$ Increasing the amount of functional employees allows managers to distribute and increase workloads, but the functional departments will reach a point where they can no longer increase efficiency, causing the company to stagnate.

Managers can only make decisions that affect the people they supervise. Functional managers can make decisions for their personnel, but only top managers maintain decisionmaking authority that affects multiple functional areas. This centralized decision-making limits lower managers and causes the organization to have a single point of failure in the event the top manager is not available. ${ }^{12}$

\footnotetext{
${ }^{9}$ Maurer, foreword to Organization Charts, xi.
}

${ }^{10}$ Harold Kerzner, PM Best Practices, 2nd ed. (New York, NY: International Institute for Learning, 2010), 2.

${ }^{11}$ Anne Robert Jacques Turgot, Observation sur un Mémoire de M. de Saint-Péravy (1767), in Euvres de Turgot et Documents le Concernant, vol. 2, ed. Gustave Schelle (Paris: Librairie Felix Alcan, 1914, 644, quoted in Stanley Brue and Randy Grant, The Evolution of Economic Thought, 8th ed. (Mason, OH: South-Western Cengage Learning, 2007), 46.

${ }^{12}$ Hatch and Cunliffe, Organizational Theory, 299. 
Specialization can cause managerial parochialism, where functional managers' focus on their direct employees without considering what is best for the whole organization.

Organizational growth combines managers' responsibilities across functional areas, reducing their specialization. Managers fail to understand all aspects of the processes as they move up the supervisory ladder, relying on the input from subordinates in other functional areas. ${ }^{13}$

The functional organization structure works best for smaller organizations in an open system. The lack of cross-departmental communication causes a lag in decision making as leaders determine the correct decision maker. ${ }^{14}$ Organizational expansion increases the administrative staff, differentiation, and centralization of decision-making while reducing the ability to integrate.

\section{Self-Contained Unit Structure}

The self-contained unit structure outlined by Maurer is a direct correlation to Galbraith's mode of the same name and equivalent to the divisional structure referenced by several other authors. A self-contained unit is similar to multiple functional structures under an umbrella organization. Each unit has the required functions to operate independently but reports to a higher manager who coordinates their efforts. The division of human resource requirements to units increases the amount of managerial responsibilities the managers oversee. They spread these tasks to their directly supervised employees.

Managers break the units into geographical or product specific focused organizations, increasing the need for supervisors. Retail stores are a prime example of this concept; individuals run the stores within the limits of their organization so senior management does not focus on

${ }^{13}$ Gareth R. Jones and Jennifer M. George, Contemporary Management, 5th ed. (St. Louis, IL: McGraw-Hill/Irwin, 2008), 394.

${ }^{14}$ Maurer, foreword to Organization Charts, xi. 
daily activities. Senior managers track store progress and compare the various stores, which learn from each other and implement best practices across the organization. ${ }^{15}$

The self-contained units have similar benefits and drawbacks involving integration, centralization, and specialization at the micro level. The self-contained unit does increases horizontal communication within the unit. Cross unit integration at the macro level is problematic because the units do not perform the exact same functions. Even units producing the same product in geographically different areas have problems that do not translate from one region to another. The organization does not benefit from lessons within specialties as well because the employees are not co-located. Senior management must force lessons learned. Centralized decision-making occurs in each self-contained unit and at the overall organization level, but the smaller units allow managers to focus on their unit without worrying about impacts to the overall organization.

Self-contained unit organizations grow at a controllable rate. The organization can build a factory or establish an additional office when the workload of a single unit exceeds capacity. The nature of self-contained units requires organizations to grow exponentially, expanding every aspect of the organization instead of increasing one functional area as demand increases. An organization cannot increase the design section to produce a product without establishing an administration or production section. Existing units could focus on research and development with the goal being to emplace a new product, but this team would then form the nucleus of a new self-contained unit.

\footnotetext{
${ }^{15}$ Jones and George, Contemporary Management, 396.
} 


\section{Matrix Organization}

Matrix organizations function based on the theories of Mary Parker Follett, increasing lateral relationships and pushing decision making to lower levels. ${ }^{16}$ Organizations focused on project delivery use the matrix organization to develop project teams and increase organizational flexibility. ${ }^{17}$ The term matrix organization incorporates a functional branch of project managers to control project teams comprised of members from the other functional branches. These matrices balance the requirements between the functional and project managers. ${ }^{18}$

Matrix organizations have more administrative components because each functional specialty has managerial staff in addition to the project managers. The multiple managers increase employee reporting requirements and forces employees to conduct administrative work. Employees must report the hours they work on each project to their functional managers, balancing their work between multiple projects and functional tasks. The increased managerial staff increases the need for meetings so managers ensure each member of the team understands the entire situation. ${ }^{19}$

The matrix structure decreases the vertical differentiation, but requires employees to report to multiple supervisors simultaneously. Employees balance their time while ensuring their priorities nest with either the project managers they work for or the functional supervisor who controls their evaluations. ${ }^{20}$ Functional managers can supervise more employees because the

53.

${ }^{16}$ Jones and George, Contemporary Management, 62-63.

${ }^{17}$ Jones and George, Contemporary Management, 399; Galbraith, Organization Design,

${ }^{18}$ Project Management Institute, A Guide to the Project Management Body of Knowledge: $P M B O K^{\circledR}$ Guide, 5th ed, (Newton Square, PA: Project Management Institute, Inc., 2013), 22.

${ }^{19}$ Gareth Morgan, Images of Organization (Thousand Oaks, CA: SAGE Publications, Inc., 1997), 54.

${ }^{20}$ Jones and George, Contemporary Management, 399. 
employees output goes to separate project managers. The increased span of control reduces the need for multiple intermediate supervisors in functional areas.

The major benefit of a matrix organization is the increased integration across functional areas. The project team meetings allow production personnel to identify future problems during the design phase to ensure there are no rework requirements. Good project managers involve potential customers throughout the process to ensure the project team remains on task to prevent problems. The added integration increases organizational flexibility as functional managers assign personnel to project teams with the right experience for each project. ${ }^{21}$

The incorporation of functional employees across the project team does not affect specialization requirements. Members of the team focused on engineering tasks continue to complete those tasks while members of the financial section complete budgetary tasks for the project team. The incorporation of a project management section causes potential problems based on the project manager's background. Some project managers may be certified Project Management Professionals while others may rise through the functional ranks and transfer to project management. ${ }^{22}$ Functional employees ensure the project managers understand the issues for their functional area, and the effect those issues have on the organization.

Senior managers delegate decision-making authority to project and functional managers based on the requirements of the organization. The decentralization of decision-making increases the organization's ability to react to changes in the environment. Senior managers make decisions that affect the entire organization while allowing subordinates to solve lower level problems that

${ }^{21}$ Jones and George, Contemporary Management, 399; Morgan, Images of Organization, 55; Galbraith, Organization Design, 163; Hatch and Cunliffe, Organization Theory, 303

${ }^{22}$ For more information about the Project Management Professional (PMP) certification see "Project Management Professional (PMP) ${ }^{\circledR}$," Project Management Institute, accessed October 16, 2014, http://www.pmi.org/Certification/Project-Management-ProfessionalPMP.aspx. 
only affect projects or functional areas. Project managers focus on completing their projects while functional managers ensure project managers use the functional employees effectively.

The flexible nature of matrix organizations allows for increases and decreases with demand. Functional managers, to include the manager of project managers, monitor employee workload and task accomplishment. They conduct hiring or separation actions as workloads increase or decrease while accomplishing assigned tasks. Excessive growth strains managerial positions, causing the organization to increase the managerial levels, increasing operating costs.

\section{Hybrid Organization}

Hybrid organizations attempt to mitigate the weaknesses of the other organization types while capitalizing on their strengths. Unlike the three organization types above, hybrid organizations do not have inherent benefits and drawbacks. These organizations exist because managers and organizational designers identified a benefit for using an organization type at one level of the organization that did not apply to the organization as a whole. The other levels use organizational structures that benefit them.

Large organizations operating in multiple different areas may establish self-contained units on the exterior of the company's reach while maintaining a functional structure at the company headquarters. Jones and George documented the structure of Federated Department Stores, which own Macy's and Bloomingdales. These two organizations operated as selfcontained units with geographic responsibilities while reporting to a functional corporate headquarters. $^{23}$

The lack of unity is the primary weakness of a hybrid organization with a functional senior management and self-contained operating units. Managers of self-contained units must address problems with more than one person at the higher level of management in order to find

\footnotetext{
${ }^{23}$ Jones and George, Contemporary Management, 402.
} 
the best solution. US Army units face this problem. The battalion is a self-contained unit that relies on a staff organized functionally at the brigade level. The brigade staff provides advice to battalion counterparts, but the battalion officers report to the battalion commanders. An example of this is that the battalion commander evaluates the battalion personnel officer, but the battalion personnel officer receives guidance on how to perform functional tasks from the brigade personnel officer. The battalion personnel officer prioritizes the battalion commander's requirements over the brigade personnel officer because the battalion commander writes his evaluation.

\section{Chapter 1 Conclusion}

Organizational developers provide senior managers with the benefits and drawbacks of each structural type during the creation or change of an organization based on the organization's objectives and operating context. There are no perfect solutions for an organization regardless of the industry. Not every engineering construction firm uses a matrix organization, nor does every retail chain use regionally self-contained units. Functional organizations facilitate specialization in branches but lack the cross-departmental communication links to work effectively in large organizations. Self-contained units provide all the companies resources in a small package, but require exponential growth to maintain capacity of each unit. Matrix organizations integrate the functional branches and provide companies a project focused approach to conducting operations. The matrix structure allows for incremental growth, but large growth increases the managerial demands and overhead costs. Hybrid organizations allow companies to mix and match structures at the different hierarchical and geographical levels, balancing risks and rewards.

Leaders face a complex problem when determining how to structure their organizations. They must consider the constraints placed on the organization in addition to the span of control, hierarchical levels, horizontal integration, specialization, control, and growth. Laws, the senior management, the customer, and the designer's own biases all constrain an organizational structure 
and functionality. ${ }^{24}$ The primary laws that constrain US government agencies are United State Code, while senior military management applies constraints to the organizations through engineer and Army regulations. Customers require contact with the organization, with the actual conduct of work remaining a byproduct of the agreement for completion. The organizational culture or social system drives the designer's biases, and is the largest impediment to organizational change. ${ }^{25}$ The United States Army Corps of Engineers (USACE) and the US Army engineer brigades must comply with the same legal requirements, leaving the management, customer, and individual biases to apply separate constraints on the structure. The next chapter addresses the structure of the USACE districts and US Army engineer brigades, describing how legislative and managerial regulations direct the organization structure.

${ }^{24}$ Bryan Lawson, How Designers Think: The Design Process Demystified, 4th ed. (New York, NY: Elsevier Ltd., 2006), 90.

${ }^{25}$ Howard M. Carlisle, Management: Concepts and Situations (United States of America: Science Research Associates, Inc., 1976), 448. 


\section{Chapter 2}

\section{Case Study Selection}

The USACE is a subsection of the US Army that reports directly to the Army Chief of Staff and Secretary of the Army. US Army engineer brigades belong to the operational army, reporting to Forces Command, US Army Pacific, the US Army Reserves, or the Army National Guard. US Army engineer colonels command the majority of the USACE Districts and the US Army engineer brigades, with some exceptions for smaller USACE districts and larger engineer brigades in the Reserves or National Guard. A centralized Army board selects colonels for command, and the Chief of Engineers decides who commands the USACE districts and the regular Army engineer brigades. Commanding each type of unit is comparable because individuals do not receive special training for either type of command.

While prominent in the US Army Reserves and Army National Guard, there are still engineer brigade headquarters in the active duty force that may lend a management structure more able to control project cost growth. Engineer brigades use self-contained hierarchical units to oversee projects, with functional managers advising the brigade commander. Evaluating how US Army engineer brigades conduct project planning and execution may provide a structure for districts to follow that controls project growth more effectively.

This chapter outlines the structure and cost growth metrics for the USACE districts and active Army engineer brigades. The first two sections document the structure of a USACE district and provide an analysis of the districts' project cost growth. The next two sections summarize the force structure and standard operating procedures for the active duty engineer brigades while demonstrating an ability to control project cost growth. 


\section{USACE District Structure}

USACE is one of two agencies specified in law that the Secretary of Defense uses to supervise military construction projects. ${ }^{26}$ This forces combatant commanders and their subordinates to hire USACE for construction oversight and prevents USACE from rejecting projects appropriated by Congress. Proper management of large military construction projects, however increases the likelihood that customers will hire USACE to oversee smaller projects.

USACE experienced an organizational structure change in the late 1980s when Assistant Secretary of the Army for Civil Works Robert W. Page suggested USACE districts use a project management structure similar to a matrix organization. ${ }^{27}$ The new structure introduced the role of the Deputy District Engineer for Programs and Project Management while maintaining separate functional responsibilities for engineering, construction, and planning. Lieutenant General Henry Hatch implemented the organizational change when he became the Chief of Engineers in July 1988. ${ }^{28}$ After two years of struggle with clarifying roles and responsibilities of project managers, USACE districts changed from a functional to a matrix organization.

Today, colonels command thirty-two of the USACE districts, but each district is slightly different in their overall organization structure. ${ }^{29}$ The districts contain functional divisions, including engineering and construction, program and project management, contracting, real

${ }^{26}$ Military Construction Codification Act, US Code 10 (1982), § 2851.

${ }^{27}$ Robert P. Grathwol and Donita M. Moorhus, Bricks, Sand, and Marble: US Army Corps of Engineers Construction in the Mediterranean and Middle East, 1947-1991, (Washington, DC: Government Printing Office, 1992), 610.

${ }^{28}$ Ibid., 612.

${ }^{29}$ See http://www.usace.army.mil/Locations.aspx for links to each USACE district. All provide the biography of the leaders and their rank. 
estate, resource management office, information management office and others. ${ }^{30}$ A civilian General Schedule grade fifteen Deputy District Engineer conducts oversight of the project aspects of the organization, while a lieutenant colonel Deputy District Commander oversees the human resources and resource management aspects of the district. The district commander has ultimate control of each division of the organization.

The program managers work with the customers to develop long-term plans for the customers' organizations and inform the functional managers of future work requirements. Project managers oversee the budgeting, scheduling, and resourcing for every aspect of the projects undertaken by the district. These individuals coordinate with the contracting division to get the project awarded and maintain contact with the customer to provide updates received from the contracting officer representative or project engineers overseeing construction. Program and project managers reside at the district offices, with the occasional placement of a regional project manager at a field office near the construction.

Districts either consolidate the engineering and construction sections into a single division with two branches, or assign each as a separate division. Designers reside in the engineering branch to create designs or provide specialized oversight to the construction branch. The individuals in this branch are typically professionally licensed engineers in their respective fields. The construction branch contains project engineers and construction quality assurance representatives, who have practical engineering and construction experience as well as contract administration training. These individuals reside in field offices located at or near the construction sites to provide oversight.

${ }^{30}$ Tables of distribution and allowances accessed from the Force Management System (FMSWeb) to show the allocation of personnel for each section of the USACE districts. The organizations include 2015 Mississippi Valley Division TDA, 2015 North Atlantic Division TDA, 2015 Pacific Ocean Division TDA, 2015 South Pacific Division TDA, 2015 South Atlantic Division TDA, 2015 Engineer Division Southwestern TDA, 2015 Engineer Division Great Lakes and Ohio River TDA, 2015 Engineer Division Northwestern TDA, and 2015 Engineer Division Transatlantic TDA. Information accessed on December 11, 2014. 
The contracting division of a district contains personnel with legal authority to "enter into, administer, or terminate contracts" provided by an appointing authority as documented in the federal acquisition regulation. ${ }^{31}$ The agency head approves these individuals, who then complete the desired requirements to maintain their contracting warrant. Contracting officers consolidate at the district headquarters for mutual support and shared access to contract specialists who assist with consolidation of paperwork and drafting correspondence.

USACE districts have a large managerial population, even if their personnel do not oversee other employees. The program and project managers do not produce anything for external use other than communication. There are minimal levels of management because of the matrix structure. Functional managers only focus on administrative tasks, which increase the number of employees they can supervise. The districts' organizational problems begin when evaluating the horizontal communication. Construction personnel have difficulty contacting the project manager and the contracting officer to render an opinion about differences between how the construction members and the contractors interpret the contract. Contracting officers must intervene because contractors strive to fill the terms of the contract at the cheapest cost in order to increase profits and construction personnel enforce the strictest spirit of the contract. Rework required to remedy the deficiency created because a contractor continued to until the contracting officer intervenes creates project cost growth. The districts maintain specialization within the functional branches by sharing lessons and conducting training. Districts reach out to the USACE Centers of Excellence and Communities of Practice if they do not have the knowledge internal to the district. They face the same control issues of every matrix organization. Project growth occurs because functional employees do not follow the same priorities as project

${ }^{31}$ Federal Acquisition Regulation (FAR), Part 1 - Federal Acquisition Regulations System, Subpart 1.6 Career Development, Contracting Authority, and Responsibilities (2014), Subpart 1.602-2, accessed December 11, 2014, http://www.acquisition.gov/far/html/Subpart\%201_6.html. 
managers, resulting in changes to the project. The following section demonstrates the need to control cost on USACE military construction projects.

\section{USACE Cost Control Analysis}

The USACE headquarters provides analysis to the division commanders every quarter through the Command Management Review. The review allows commanders and staff above the district level to "conduct strategic and operational reviews of performance." ${ }^{32}$ According to the Command Management Review for the fourth quarter of fiscal year 2014, less than eighty percent of the military construction projects had less than five percent cost growth on a sliding five-year scale since fiscal year 2012. ${ }^{33}$ This means at least twenty percent of projects completed by USACE for military organizations in the last five years increased in cost to the customer by at least five percent. As a comparison, the Clark County Public Works Department in Las Vegas experienced a cost growth average of less than five percent from 1991 to 2008 while the Indiana Department of Transportation maintained a cost growth average of less than four and a half percent between 1996 and $2001 .^{34}$

The Command Management Review goes on to identify the average cost growth for fiscal year 2014 at five and six tenths of a percent. Engineering changes, those attributed to

${ }^{32}$ Engineer Regulation (ER) 5-1-15, US Army Corps of Engineers Strategic Management (Washington, DC: US Army Corps of Engineers, 2009), 2-16.

33 "Command Management Review: 4QFY14" (Washington, DC: Headquarters, US Army Corps of Engineers, 2014), slide 23.

${ }^{34}$ Pramen P. Shrestha, Leslie A. Burns and David R. Shields, "Magnitude of Construction Cost and Schedule Overruns in Public Works Projects," ed. Manoj Jha, Journal of Construction Engineering Volume 2013 (October 2013): Article ID 935978, accessed February 11, 2015, http://www.hindawi.com/journals/jcen/2013/935978/; Claire Bordat et al., "FHWA/IN/JTRP2004/7: An Analysis of Cost Overruns and Time Delays of INDOT Projects," (West Lafayette, Indiana: Purdue University), i, accessed February 11, 2015, http://docs.lib.purdue.edu/cgi/viewcontent.cgi?article=1482\&context=jtrp. 
USACE to correct issues in the contract plans, comprised two and a half percent of the changes. ${ }^{35}$ User requested changes and changes required because the elements under the surface of the site did not meet expectations, each accounted for one percent of project growth. ${ }^{36}$ USACE formerly classifies user requested changes and differing site conditions as uncontrollable changes, but increased communication between the USACE, the customer, and the contractor performing the work would reduce user requested changes. An organizational structure focused on reducing these costs and overall project development would prevent these project growths.

The Chief of Engineers and Engineer Division Commanders, as well as their staffs, know USACE districts do not control project cost growth because these individuals participate in the Command Management Review. Mr. Paul DesRoches from the South Atlantic Division identified the consistent project growth in military construction projects for his division. He proposes, as stated above, that USACE districts can control changes perceived as uncontrollable through communication. He believes project managers must focus funds and attention on the design even if the benefits are not immediate. ${ }^{37}$

The ideas Mr. DesRoches proposes are not new, but demonstrate district leadership does not enforce existing policies. The analysis of how USACE conducts project management and oversight during project acceptance through execution shows the assignment of these tasks to the associated functional areas. Project managers do not have reward or punishment authority over

35 "RMS User's Guide: Software Version 2.38" (Los Angeles, CA: RMS Center, Los Angeles District, US Army Corps of Engineers, 2012), 9-5, accessed February 8, 2014, http://rms.usace.army.mil/datafiles/RMS_QCS_Manuals/rms_manual_2_38.pdf; "Command Management Review: 4QFY14", slide 28.

36 "RMS User's Guide: Software Version 2.38", 9-5; "Command Management Review: 4QFY14", slide 28.

${ }^{37}$ Paul DesRoches, "Seeking Fundamental Issues: HQUSACE FY14 AAR, Nov 2014," (Atlanta, GA: South Atlantic Division, 2014), slides 2, 8, and 9. 
project members, allowing project members to ignore duties with impunity. The next sections show how an active duty engineer brigade controls cost through their structure.

\section{US Army Engineer Brigade Structure}

The Department of the Army dictates the personnel structure of the active duty engineer brigades. The structures, displayed on each unit's modified table of organization and equipment, undergo a rigorous review process by several individuals with over twenty years of experience. Moreover, the units can submit recommended changes to the organizational structure through the annual command plan process, which allows the unit to increase overall efficiency by adding or reducing positions. ${ }^{38}$ Each unit has, theoretically, the most efficient personnel structure to execute its military troop construction missions.

The Army prescribes a maximum of one manager to five subordinates. ${ }^{39}$ At the lower levels, the managers have minimum supervisory duties, but these increase up the organization. The span of control increases the vertical communication levels, reducing the risk of vertical and horizontal miscommunication while increasing the spread of lessons learned.

The US Army has four active duty engineer brigades, possessing the capability to complete construction projects from inception through completion. ${ }^{40}$ An Army colonel leads the brigade with an operational staff consisting of an executive officer, an operations officer, a

${ }^{38}$ Army Regulation (AR) 71-32, Force Development and Documentation (Washington, DC: Government Printing Office, 2013), 5.

${ }^{39}$ Army Doctrinal Reference Publication (ADRP) 6-0, Mission Command (Washington, DC: Government Printing Office, 2012), 2-16.

${ }^{40}$ The fifth engineer brigade, 2nd Engineer Brigade, is set to deactivate in the summer of 2015 and therefore not included in this analysis. 
logistics officer, a personnel officer, and a communications (signal) officer. ${ }^{41}$ The operations officer, a lieutenant colonel, uses the design engineer, a lieutenant colonel, to oversee the construction design and management process with a staff of approximately twenty-two personnel. Each brigade has at least one construction battalion, led by a lieutenant colonel, to take the project from the design to construction completion.

Each brigade operates differently, but a review of three standard operating procedures reveals the brigades borrowed ideas from each other when formulating their standard operating procedures. ${ }^{42}$ A colonel or lieutenant colonel with at least fifteen years of military experience reviewed each of these standard operating procedures. These documents encapsulate best practices for the organizations to provide quality projects and prevent issues like project growth.

Engineer Brigade Cost Control Analysis

Two of the active engineer brigades participate in humanitarian civil assistance missions throughout countries in the Pacific region. Elements of the 130th Engineer Brigade and the 555th Engineer Brigade participate in exercise Balikatan in the Philippines, Cobra Gold in Thailand, Ayara Guardian in Thailand, Hunuman Guardian in Thailand, and Khaan Quest in Mongolia. These missions provide a sample to determine if engineer brigades effectively prevent or reduce project growth by having a self-contained hierarchical organization responsible for the planning and oversight of construction projects.

${ }^{41}$ Modified tables of organization and equipment accessed from the Force Management System (FMSWeb) to show the allocation of personnel for each section of the Army engineer brigades. The organizations include 20th Engineer Brigade MTOE, 36th Engineer Brigade MTOE, 130th Engineer Brigade MTOE, and 555th Engineer Brigade MTOE. Information accessed December 9, 2014.

42 "36th Engineer Brigade Construction SOP" (Fort Hood, TX: 36th Engineer Brigade, 2013); "130th Engineer Brigade Construction Standard Operating Procedures"; "555th Engineer Brigade "Willing and Able": Construction Standing Operating Procedures (CSOP) [Draft]" (Fort Lewis, WA: 555th Engineer Brigade, 2014). 
Reviewing the after action reports from nine previous exercises, US Army units had a project growth of negative fourteen and ninety-five hundredths of a percent. ${ }^{43}$ The units did not experience schedule growth, but did request and execute more projects than originally planned during several of the exercises. The local government accepted every project completed during these exercises, and only two sites during two separate exercises appear to have had a scope reduction due to project duration limits. Each of these exercises also incorporated three to eight separate project sites, resulting in over twenty-five completed structures delivered under budget.

\section{Chapter 2 Conclusion}

The active duty engineer brigades demonstrate their organizations conduct construction projects without project overruns. There are differences between the types of projects the organizations complete that could affect the cost growth. First, USACE military construction projects have a minimum cost of $\$ 750,000$, while the Army brigades' projects cost between $\$ 160,000$ and $\$ 440,000 .^{44}$ The larger projects are more complicated, but not necessarily more complex. Every project reviewed for the Army engineer brigades occurred in a foreign country requiring local procurement of materials and reliant on the exchange rate between the dollar and the local currency. Following practices set out by the Project Management Institute allows USACE and the Army engineer brigades to take advantage of proven project management

${ }^{43}$ Projects accessed from the Oversees Humanitarian Assistance Shared Information System (OHASIS). The exercises selected contained at least one subordinate unit from the 130th Engineer Brigade or 555th Engineer Brigade. The project review included all projects reported as complete, thirty day after action review complete, or ninety day after action review complete. The system only had accurate information for projects from 2009 until today, with information appearing suspect for prior years and therefore excluded. The project numbers evaluated are: 9182, 11035, 12550, 13045, 13294, 21913, 22971, 23354, and 23359. Information accessed December 9, 2015.

${ }^{44}$ National Defense Authorization Act for Fiscal Year 2004, US Code 10 (2003), §2805 sets the limit for MILCON funding above \$750,000; project values based on information from OHASIS. 
processes. ${ }^{45}$ Second, the engineer brigades complete the construction themselves, which allows them to balance the cost of supplies with training requirements and execute additional projects without additional cost. Supply overages transition to additional projects for the customer because the labor is not included in the cost of work. Chapter Five addresses these differences, but project management practices introduced in chapters Three and Four show how to avoid these aspects of project growth.

The USACE districts are hybrid organizations that use functional employees to complete projects using a matrix structure where the project manager lacks authority over the team members. The structure results in an average project growth of over five percent for the last three years. Army engineer brigades are hybrid organizations with a functional structure in an advisory role to self-contained units, resulting in over-estimated budgets that prevent project growth. Project growth and overestimation demonstrate a lack of planning and control, but project growth and requests for more funds destroys the trust between a customer and the USACE districts. The following chapter looks at how these organizations control cost during project selection and design.

${ }^{45}$ Project Management Institute, A Guide to the Project Management Body of Knowledge: PMBOK ${ }^{\circledR}$ Guide, 554. 


\section{Chapter 3}

\section{Cost Control Procedures during the Selection and Design Phase}

Organizations need a business process regardless of the structure. The Project

Management Institute set the standard for project management when the organization began in 1969. The not-for profit institute provides a framework to manage projects through standardized processes, which USACE and the Army engineer community at large recognize. The US Army added an additional skill identifier for those soldiers who obtain their Project Management Professional certification from the Project Management Institute in 2013. ${ }^{46}$ USACE directly references A Guide to the Project Management Body of Knowledge (PMBOK ${ }^{\circledR}$ Guide) published by the Project Management Institute in USACE's overarching Engineer Regulation for how USACE conducts project management. ${ }^{47}$ Additionally, the USACE Project Management Business Process Manual used the PMBOK Guide as the industry standard and a guidepost for USACE business processes. ${ }^{48}$

The PMBOK Guide ${ }^{\circledR}$ outlines five process groups to ensure a project flows through its life cycle. These process groups include initiating, planning, executing, monitoring and controlling, and closing. ${ }^{49}$ Organizations select the processes required to control their projects because each process may not be applicable to every project. ${ }^{50}$

\footnotetext{
${ }^{46}$ Kriten Jenner, "Changes Coming to the Engineer Officer Career Field"
} http://usaes.armylive.dodlive.mil/2012/01/20/changes-coming-to-the-engineer-officer-careerfield/ posted January 20, 2012, 7:26 pm; accessed February 13, 2015.

${ }^{47}$ Engineer Regulation (ER) 5-1-11, USACE Business Process (Washington, DC: US Army Corps of Engineers, 2006), 1.

48 "Project Management Business Process Manual: Version 1.0" (Washington, DC: US Army Corps of Engineers, 2009), 3.

${ }^{49}$ Project Management Institute, A Guide to the Project Management Body of Knowledge: PMBOK ${ }^{\circledR}$ Guide, 49.

${ }^{50}$ Ibid., 48. 
Identifying variables and determining how to mitigate their effects during project selection and design allows an organization to apply assets to address those issues. Failure to identify issues results in a greater risk of cost increases due to unplanned activities.

Organizations control a project's characteristics during selection and design with less cost than if changes occur in the later life of the project. ${ }^{51}$

The PMBOK Guide ${ }^{\circledR}$ does not address project selection in the strictest sense because a project manager does not select projects. It does outline that organizational strategy guides and directs how the organization manages the projects it selects. ${ }^{52}$ The organization's leadership ensures the projects selected support the organization's strategic goals and the individuals controlling the project understand how the project fits into the organization's strategy.

Project design can include processes from the initiating and planning process groups or it can be its own phase, following every process group. The USACE and Army engineer brigades use both approaches depending on the type of project. Dividing the project into design and execution phases increases the control and reduces the opportunity for cost growth because the design phase results in a complete product. This chapter describes how USACE and Army engineer brigades control cost during project selection and design.

\section{USACE Project Selection and Design}

Military construction project growth occurs after USACE awards the contract for construction, but selecting a project without properly planning and resourcing it provides areas for growth to occur in the future. Program managers work directly with the customers on a daily basis. These individuals maintain the customer's requirements and assist in projecting future

${ }^{51}$ Project Management Institute, A Guide to the Project Management Body of Knowledge: PMBOK® Guide, 39.

${ }^{52}$ Ibid., 15 
work to ensure USACE can properly manage and resource the customer's needs. Customers generally work through the program manager for all new projects, but USACE maintains a "one door to the Corps" policy, which allows customers to contact any employee to get information. ${ }^{53}$ Regardless of which USACE employee receives the request, they forward it to the Deputy for Programs and Project Management to accept the work. ${ }^{54}$

The Deputy for Programs and Project Management assigns a program manager to determine if the work meets the requirements for USACE to accept. This includes coordinating with the resource managers to ensure the district has the personnel available. ${ }^{55}$ If a resource manager cannot support the request, the issue travels in the vertical stovepipe until either the resource provider, middle management, project review board (established at the district level for current year activities), or corporate board (including the district commander) determine a solution to the shortage. ${ }^{56}$

Requiring the Deputy for Programs and Project Management to approve project selection puts the onus on one person, but this person does not have responsibility over all aspects of the organization. A failure in communication along informal channels will result in a failure for the functional managers to provide adequate resources to support the project. Even though USACE provides a business practice, functional managers have requirements that are not in line with the project managers or the program and project management division. Focusing on these requirements detracts from the ability for members of the construction branch to fulfill the requirements of the project, even if other requirements (i.e. training), need to be completed.

${ }^{53}$ Engineer Regulation (ER) 5-1-10, Corps-Wide Areas of Work Responsibility (Washington, DC: US Army Corps of Engineers, 2009), 1.

54 "Project Management Business Process Manual: Version 1.0", 11.

${ }^{55}$ Ibid., 12-13.

${ }^{56}$ Ibid., 16, 133, 138. 
Project planning follows the selection phase. This is the largest phase of the project management business process and involves developing a project delivery team from every functional area of the district. The project manager develops a project management plan that describes how the project delivery team supports the project, but does not alleviate functional managers of their responsibility to control their members. The result is a strong matrix organization, but where the functional managers maintain primacy over the employee's task management and the project managers control the funding the employees use for work completion. ${ }^{57}$

The project management team collaborates to build a rough activity schedule for the project after completion of the project scope. ${ }^{58}$ The project manager relies on specialized personnel from the resource managers. The functional manager from the construction branch wants multiple people to review the plan, but project managers constrain the functional managers with budgetary limits. The functional manager's desire for increased horizontal communication and project understanding conflicts with the project manager's budgetary control. Failing to balance these two desires causes designers to omit required activities and causes project growth. While the opinions among several construction companies are mixed, the general thought is change orders occur because project managers fail to identify all the requirements at the beginning of a project. ${ }^{59}$ The failure to identify all the activities required falls squarely in the construction branch, but the project manager shares responsibility. Modifying the contract when

\footnotetext{
${ }^{57}$ Project Management Institute, A Guide to the Project Management Body of Knowledge: PMBOK® Guide, 22.

58 "Project Management Business Process Manual: Version 1.0", 39.

${ }^{59}$ Ulf Wolf, "The Change Order: Blessing or Curse?" Construction Dimensions: Published for Contractors by the Association of the Wall and Ceiling Industry (January 2014), accessed February 15, 2015, http://www.awci.org/cd/showArticle.pl?id=1515.
} 
quality assurance personnel identify the issue during construction could result in thousands of dollars in project growth.

The project acquisition process follows the development of the activity schedule.

USACE conducts projects in two ways, design-build projects and design-bid-build projects. ${ }^{60}$ Design-build contracts experience project cost growth because project managers fail to gain complete understanding of the customer's desired outcome, the members of the engineering branch misinterpret the project manager's direction, or the contracting office fails to incorporate all the documents needed to award the contract. Design-bid-build projects suffer from these horizontal communication issues during the procurement or development of the design portion of the project. USACE limits these misunderstandings by requiring a project management plan to address items including the project's scope, customer requirements, schedule requirements, and procedures to manage changes to the project. ${ }^{61}$ USACE elevated the decision from the project development team to include the chief of engineering and the chief of construction to ensure proper buy-in from the branch responsible for direct project oversight. ${ }^{62}$

The development of the project management plan and the project scope is an iterative process where the project manager works with the customer to define the requirements, then incorporates the input of the functional employees as required. ${ }^{63}$ Issues arise when project

${ }^{60}$ The primary difference is design-build projects have one contracting process while design-bid-build projects use one process to design the project completely and another to complete the project. USACE uses design-build projects to transfer the risk of a failed design to a single contractor while reducing the time needed to complete the project because the project only requires one procurement process. When using a design-bid-build process, USACE either does the design in-house using the engineering branch or awards a contract for the design.

61 "Project Management Business Process Manual: Version 1.0", 32.

${ }^{62}$ Engineer Regulation (ER) 1180-1-9, Design-Build Contracting (Washington, DC: US Army Corps of Engineers, 2012), 2.

63 "Project Management Business Process Manual: Version 1.0", 31. 
managers fail to gain consensus from the project development team and must go to functional managers for approval, particularly in the construction branch.

The construction branch locates its field offices near the construction sites, while the functional managers of the construction branch maintain offices in the district headquarters with the program and project managers, resource management, and contracting. Construction managers may overrule the concerns of the field offices and approve the scope of a project because they possess the same regional biases as the project managers and do not understand the concerns of the field office. This is of particular concern when the district office is in one state or country and the field offices are in another. ${ }^{64}$ Cost growth occurs because the original concerns of the field offices come to fruition after the procurement process.

These communication issues intensify during design-bid-build projects, because the engineering branch is also located in the district offices. While the members of the engineering branch are typically licensed professional engineers, they may not have the understanding of construction practices in the local area to provide an adequate design. Inclusion of building practices from other areas causes confusion to the contractor selected to build the project and results in project growth to clarify the issue. An example of this is the inclusion of a clause for European Union safety practices for a project in Turkey, which is not a member of the European Union. ${ }^{65}$ Another example is the inclusion of a clause required for contracts in the United States

\footnotetext{
${ }^{64}$ Websites for each engineer district show the location of their area and resident offices. Examples include Europe District: http://www.nau.usace.army.mil/Locations/DistrictOffices.aspx, Far East District: http://www.pof.usace.army.mil/Locations/ResidentandAreaOffices.aspx, Omaha District: http://www.nwo.usace.army.mil/Locations.aspx, and St. Paul District: http://www.mvp.usace.army.mil/Locations/DistrictMapsLocations.aspx.

65 "Solicitation, Offer, and Award, W912GB-15-R-0008" (Wiesbaden, Germany: US Army Corps of Engineer, Europe District, 2015), 7, accessed February 15, 2015, https://acquisition.army.mil/asfi/sol_attachment_viewer.cfm?psolicitationnbr=W912GB15R0008 \&FILE_NAME=C\%2D05\%5FW912GB\%2D15\%2DR\%2D0008\%5FTurkeyMATOCSol\%2Epdf \&ext= (.pdf)\&isXML=N, accessed February 15, 2015.
} 
when the contract results in furniture provided to a clinic in Grafenwoehr, Germany. ${ }^{66}$ These errors appear simple, but cause confusion to the contractor if not identified in the bidding process. The misunderstandings result in engineering change modifications that may cause project growth because the contractor did not plan for the additional work.

The USACE designed the work breakdown structure it uses for all military construction projects to support design-build contracts. ${ }^{67}$ The process requires project managers use engineering and construction personnel to create investigative products to reduce the amount of unforeseen site conditions and conduct incremental design reviews to ensure changes are not required during construction. ${ }^{68}$ These requirements increase the horizontal communication across the functional areas. Unfortunately, the work breakdown structure only includes the construction contract award, notice to proceed on the project, and project completion during the construction phase of the contract. The matrix structure breaks down at this point and USACE develops an "over the fence" mentality as responsibility for the project passes from the project manager to the field office overseeing construction. ${ }^{69}$ The construction field office assumes responsibility to oversee the contractor's project manager, even though the field office does not have personnel trained in project management.

The field offices oversee the review of designs for design-build contracts. The field office experiences the same communication issues getting reviews and approval from the engineering branch as project managers attempting to obtain the field office's approval for design-

66 "Solicitation, Offer, and Award, W912DY-15-T-0031" (Huntsville, AL: Huntsville Engineering \& Support Center), 15, accessed February 15, 2015, https://acquisition.army.mil/asfi/attachment_viewer.cfm?Sol_Number=W912DY15T0031\&Seq_ Nbr=510651\&FILE_NAME=W912DY15T0031.pdf\&FILE_EXTENSION=pdf.

67 "Project Management Business Process Manual: Version 1.0", 177.

${ }^{68}$ Ibid.

${ }^{69}$ Kerzner, PM Best Practices, 2. 
bid-build projects. The field office leads the review of the final designs from the contractor, but must maintain contact with the team responsible for the design criteria. ${ }^{70}$ The concern for design reviews during design-build contracts is that the engineering branch imposes their own requirements not outlined in the request for proposal. ${ }^{71}$ Failing to clarify the customer's expectations during the specification and development of the request for proposal causes project modifications and cost growth. Customers envision the final project, and the project team must translate that vision to the final request. Customer requested changes occur when contractors provide a design that meets the request for proposal but the customer does not agree with the design. Regardless of future contract changes, the project moves to the execution phase after the contractor submits a one hundred percent design on a design-build project or USACE awards a contract for construction on a design-bid-build contract.

Requiring a senior level manager to select projects guarantees the project meets the district's mission, and following the organization's business processes provides a path to success. Unfortunately, horizontal communication issues cause the majority of cost growth during the project planning phase. USACE places primacy on the functional managers so the project manager does not have the authority to evaluate, promote, or provide incentives to employees on the project delivery team. Employees devote time to the manager with the most control over their future, therefore the functional manager is the first priority, resulting in project delays and cost growth. The next section evaluates how the engineer brigades control cost growth in a project's design phase by coordinating the initial timeline and budget, providing design oversight to prevent field changes, and use of standardized documents for design.

\footnotetext{
${ }^{70}$ Unified Facilities Criteria (UFC) 1-300-07a, Design Build Technical Requirements
} (Washington, DC: US Army Corps of Engineers, 2005), 1-6.

${ }^{71}$ UFC 1-300-07a, Design Build Technical Requirements, 1-6. 


\section{US Army Engineer Brigade Project Selection and Design}

Like USACE districts, Army engineer brigades assign one individual to oversee project. The brigade design engineer is responsible for every aspect of the project, and is the only manager that controls the employees assigned to the project. The design engineer assigns the brigade civil engineer to coordination with the customer and conducting the initial project design, then guarantees the overall quality of the design through an extensive design review up the hierarchical structure. ${ }^{72}$

Brigade commanders select the projects a brigade accepts based on the risks and rewards determined by the brigade operations officer. This includes rejecting projects received from their higher headquarters that a commander does not believe their soldiers can design or construct safely. ${ }^{73}$ Once accepted, project coordination passes to the technical headquarters section for oversight.

The technical headquarters section is a hierarchical subgroup within the brigade. The organization includes a civil engineer, a construction management officer, a construction engineer technician, a construction inspector, and multiple construction surveyors and drafters. ${ }^{74}$ Having a self-contained unit like this allows the design engineer to hold each person directly accountable for their ability or inability to complete their assigned tasks.

While the design engineer develops future projects for the brigade, the civil engineer coordinates directly with the customers for the current projects. The civil engineer clarifies any issues with the original scope of work provided by the customer prior to conducting an initial site survey. The civil engineer maintains an open dialogue with these potential customers to ensure

\footnotetext{
72 "130th Engineer Brigade Construction Standard Operating Procedures", 14.

${ }^{73}$ Ibid., 5.

${ }^{74}$ Ibid., 13.
} 
the project meets the customers' expectations upon the completion. ${ }^{75}$ Determining the exact outcome expected from the customer ensures the brigade can deliver the product and reduces unexpected changes after the design begins.

Having one person integrate with the customers provides a single point of failure for the engineer brigade, but it ensures a customer does not provide information about the design to an individual other than the designer. A continuous dialogue with each customer reduces the likelihood of project changes because the customer is abreast of the design process and works with the designer when establishing the scope of work. The civil engineer maintains the role of a project manager through the design phase of the project as he or she assigns individuals to complete the project's design.

The civil engineer relies on the specialized construction surveyors to conduct initial site visits to the project area in order to ensure the project meets the training requirements of the brigade. The surveyors and drafters are under the civil engineer's hierarchical authority, allowing the civil engineer to assign project priorities in accordance with the brigade's priorities. ${ }^{76}$ At times, the civil engineer may need to reach outside the self-contained technical headquarters section for construction expertise, but these individuals still reside under the supervision of the operations officer. Since a captain fills the civil engineer position, he or she outranks the individuals providing the expertise and reduces the chance of misaligned priorities between the design process, the brigade's priority list, and those of the external inspectors. ${ }^{77}$

75 "130th Engineer Brigade Construction Standard Operating Procedures", 3.

${ }^{76}$ Ibid., 13.

${ }^{77}$ For more information about the rank structure, see Civil Engineer paragraph 118, line number 2, O3; Const Ops Sgt paragraph 103, line 5, E7; Const Inspector paragraph 106, line 8, E6; Const Ops Sgt paragraph 113, line 2, E7; and Const Inspector paragraph 118, line 3, E8 from the Army engineer brigade MTOEs documented in footnote 40. 
A responsible brigade commander would ensure the brigade personnel officer assigns the role of the civil engineer to an individual with an engineering degree and professional engineering license. Doing so would increase the design quality, because the individual has proven they understand how to design through a state certification process requiring four years of previous design work and completion of two eight-hour exams. Unfortunately, of the 627 engineer captains currently serving in the active Army, only 29 have professional engineering licenses and there is no guarantee they are in engineering brigades. ${ }^{78}$

Non-licensed civil engineers, therefore, rely on the US Army technical manuals describing the basics of project design and completion. These twenty-nine documents outline basic procedures for anything from theater of operations electrical systems or carpentry to waterwell drilling operations and paving and surfacing operations. ${ }^{79}$ These standardized manuals provide a basis for designs with a proven history dating back prior to 1974 and form the backbone of designs produced by the technical headquarters section. ${ }^{80}$

Providing one point of contact for the design of the project ensures all the contributing portions combined to meet the desired result. The civil engineer may not have the experience to determine the electrical requirements of a project, but has specialized individuals within the technical headquarters section, the construction engineer technician, or other experienced

\footnotetext{
${ }^{78}$ Based on information received from the Human Resources Command Engineer Branch.

${ }^{79}$ For a list of all engineer Training Manuals see Official Department of the Army Publications and Forms website, accessed December 11, 2014, http://armypubs.army.mil/doctrine/5_Series_Collection_1.html.

${ }^{80}$ Training Manual (TM) 3-34.62, Earthmoving Operations (Washington, DC: Government Printing Office, 2012), cover page, accessed December 11, 2014, https://armypubs.us.army.mil/doctrine/DR_pubs/dr_aa/pdf/tm3_34x62.pdf, documents how TM 3-34.62 supersedes Field Manual (FM) 5-34, Earthmoving Operations (Washington, DC: Government Printing Office, 2000), which supersedes Field Manual (FM) 5-164, Tactical Land Clearing (Washington, DC: Government Printing Office, 1974), accessed December 11, 2014, http://www.globalsecurity.org/jhtml/jframe.html\#http://www.globalsecurity.org/military/library/p olicy/army/fm/5-434/toc.pdf.
} 
construction experts to call on. ${ }^{81}$ Having completed the initial design and obtained the customer's approval through the continuous dialogue process, the civil engineer submits the design for review through his hierarchical chain of command.

There is no guarantee the design engineer possesses a professional engineering license, but a larger portion of engineer lieutenant colonels possess the accreditation than junior captains. ${ }^{82}$ The design engineer reviews the plans to ensure feasibility while the construction management officer works with their assigned personnel to determine the exact material list needed to complete the project and establish the baseline budget. ${ }^{83}$ The civil engineer and construction management officer maintain open horizontal construction lines throughout the material list process to mitigate mistakes, and the surveyors provided to the civil engineer typically develop the list.

All through the design process, the project remains under the direct control of the civil engineer, with responsibility passing between his or her subordinates. The civil engineer reports to the design engineer for every aspect of the process. Maintaining a single point of contact with the customer and consolidating the design while receiving expert advice for a final design review ensures a project will not undergo project cost growth because of a misunderstanding with the customer. Reducing customer changes prevents cost growth. Even though a constructing unit takes control of building the project, the technical headquarters section continues to prevent cost growth through the construction phase.

${ }^{81}$ For more information, see Constr Eng Tech paragraph 108, line 1, W3 from the Army engineer brigade MTOEs documented in footnote 40.

${ }^{82}$ According to the Engineer Branch, two and six tenths of a percent of junior captains possessed a Professional Engineering License while twenty-one and six tenths of a percent of lieutenant colonels are licensed.

83 "130th Engineer Brigade Construction Standard Operating Procedures", 14. 


\section{Chapter 3 Conclusion}

The organizational difference between a USACE district and an active duty engineer brigade provide insight into how the project growth occurs during project selection and design. Both organizations have one individual responsible for project selection, and these individuals rely on the support of employees subordinate to them. The engineer brigade weighs the training benefits to their soldiers during project selection, while a district's concern revolves around their project mandate and regulatory restrictions. The lack of regulatory requirements for project acceptance allows the brigades to avoid risk while USACE must manage the risk accordingly.

Major concerns appear during the design portion of the project. Engineer brigades place the responsibility for project design on one individual. That individual does all the coordination between the customer and the designer while directly overseeing the design process with his subordinate employees. USACE districts spread the design process across three or four branches of the organization, with a project manager responsible for coordinating the activities of personnel in multiple areas away from the construction site. Additionally, the employees all have separate functional managers that control their time. Project managers that fail to gain consensus on the project delivery team and misinterpret the customer's desires risk future project changes due to unforeseen sight conditions, engineering changes, and customer requested changes.

Engineer brigades rely on functional managers and the organization hierarchy to select projects. They then use a self-contained unit to design the project, clearly articulating the requirements, reducing miscommunication through a hierarchical structure, and holding the designer directly responsible for the final product. The USACE project manager can pass blame to three or four separate branches because of the structure. By placing project managers in field offices and providing them engineering personnel, USACE would complete designs with limited opportunities for miscommunication. Eliminating the functional managers at lower levels consolidates the responsibility for the project design and the employees on the project manager. The next chapter reviews how each organization controls cost growth during project construction. 


\section{Chapter 4}

\section{Cost Control Procedures during Construction}

Project construction falls squarely in the executing process group, with oversight from activities in the monitoring and controlling process group. Project growth occurs in the construction phase because of miscommunication, workmanship issues, and a failure to manage change. The USACE districts and Army engineer brigades organize and develop methods to control these issues with assistance from institutional knowledge and the PMBOK Guide ${ }^{\circledR}$.

The USACE districts pass oversight of construction to members of the construction functional area. Fiscal law plays an integral part in how these individuals manage the contractors selected to complete the project. Integration between the contracting, construction, engineering, and the project management branches increases opportunities for project growth. Army engineer brigades benefit from completing the construction using a subordinate organization. They prevent cost growth during construction through an accountable hierarchical structure, experienced quality control personnel on site, and quality assurance from an organization internal to the brigade but outside the control of the construction unit.

\section{USACE Project Construction}

The USACE contracts a construction company to complete their projects. The Federal Acquisition Regulation outlines the requirements an individual must have in order to award a contract for the US government. ${ }^{84}$ The regulation does not require the contracting officer to be an expert in the work they are awarding, but USACE's includes providing a quality product to the customer. To do this, they use integrated communication systems, field offices with experienced

${ }^{84}$ FAR, Part 1 - Federal Acquisition Regulations System, Subpart 1.6 Career Development, Contracting Authority, and Responsibilities (2014), Subpart 1.602, accessed February 19, 2015, http://www.acquisition.gov/far/current/html/Subpart\%201_6.html. 
quality assurance personnel, a standardized change management plan, and regulations to guarantee quality.

The USACE districts attempt to limit miscommunications through technology. The project managers maintain project information, including resources available, the project management plan, and the project schedule in USACE's enterprise program and project management system, P2. ${ }^{85}$ This system integrates with the USACE financial system and a separate program used by member of the construction branch to monitor the projects. Project management software increases the amount of information but is not a substitute for project management practices. ${ }^{86}$

The "project execution and control phase" assigns the project managers as the leader and facilitator of the project delivery team while the functional employees ensure the contractors complete the work and oversee the technical aspects of the project. ${ }^{87}$ The contractor signs a contract with USACE through the contracting officer, and the contracting officer is the only person that can alter the terms of the contract. ${ }^{88}$ The contracting officer then assigns the project engineer overseeing the construction as a contracting officer's representative because the

${ }^{85}$ USACE p2v3, "P2 Execution Overview" in "USACE P2 Overview Movies" (video), posted April 3, 2013, accessed February 19, 2015, https:/www.youtube.com/watch?v=rZwwUV0D3kA\&list=PL459657E7965482F4.

${ }^{86}$ Mulcahy, Rita et al., PMP ${ }^{\circledR}$ Exam Prep, 8th ed. (Minneapolis, MN: RMC Publishing, 2013), 197.

87 "Project Management Business Process Manual: Version 1.0", 59.

${ }^{88}$ FAR, Subpart 1.602-2; "Contractor's Guide to Contract Administration" (Sacramento, CA: US Army Corps of Engineers Sacramento District, 2002), 2-50, accessed February 19, 2015, http://rms.usace.army.mil/datafiles\%5CContractors\%20Guide.PDF; FAR, Part 43 - Contract Modifications, Subpart 43.2 Change Orders (2015), Subpart 43.202, accessed February 19, 2015, https://acquisition.gov/far/current/html/Subpart\%2043_2.html\#wp1075008; FAR, Part 52 Solicitation Provisions and Contract Clauses, Subpart 52.2 Text of Provision and Clauses (2015), Subparts 52.243-1, 52.243-2, 52.243-3, 52.243-4, 52.243-5, 52.243-6, accessed February 19, 2015, http://farsite.hill.af.mil/reghtml/regs/far2afmcfars/fardfars/far/52_237.htm\#P357_58712. 
contracting officer does not have the technical experience to validate the contract. ${ }^{89}$ The project engineer also provides updates to the resident engineer, who is the lowest supervisory level in the construction functional group. The project engineer / contracting officer's representative becomes the focal point for all work performed by the contractor during the construction phase. Failure to gain the project engineer's allegiance to the project development team results in multiple issues because the project engineer is not beholden to the project manager for anything.

The project engineer ensures the contractor fulfills the terms of the contract, reporting issues to the contracting officer in their role as the contracting officer's representative. ${ }^{90}$ The project engineer must also ensure the contractors are completing work and receiving progress payments in accordance with the schedule to ensure the project does not fall behind schedule. The project engineer uses the quality assurance representatives to assist with observations of the contractor, receiving additional reports other than their own observations. Conflicts occur when contractors fail to adhere to the contract because they experience delays or other problems that the government did not cause. The conflicts lead to cost growth.

Resident engineers submit budget estimates and employee manning numbers semiannually based on how much work they project the contractors will complete each month. The projections typically come from the contractor's schedule. Project engineers cause resident engineers to miss projections when they report the contractor's schedule overruns. Additionally, quality assurance personnel enforcing the standards of the contract prevent the contractor from

${ }^{89}$ Procurement Instruction Letter (PIL) 2012-06-R1, US Army Corps of Engineers (USACE) Policy for Certification and Training of Contracting Officer's Representatives (Washington, DC: US Army Corps of Engineers, 2012), 3.

${ }^{90}$ Defense Federal Acquisition Regulation Supplement (DFARS), Part 201 - Federal Acquisition Regulation System, Subpart 201.6 Career Development, Contracting Authority, and Responsibilities (2014) Subpart 201.602-2, accessed February 19, 2015, http://www.acq.osd.mil/dpap/dars/dfars/html/current/201_6.htm; Army Federal Acquisition Regulation Supplement (AFARS), Part 1, Subpart 1.6 Career Development, Contracting Authority and Responsibilities, Subpart 1.602 Contracting officers, Subpart 1.602-2-90, accessed February 19, 2015, http://farsite.hill.af.mil/archive/AFARS/96-1/AFAR1.htm\#P614_26920. 
skipping steps in the construction process or using processes other than those in the contract. ${ }^{91}$ The project engineer enforces the quality assurance personnel's findings through serial letters to the contractor, but cannot direct them to do anything other than following their contract without obligating the government to pay for changes. ${ }^{92}$ Ambiguity and references to multiple standards in the contract allows contractors to interpret the contract to their benefit. If the project engineer does not have the same interpretation, the contracting officer must get involved to settle the dispute, causing a change.

Project growth caused by engineering changes occurs because of modifications to the contract that clarify the contractor's interpretation of the contract expectations. The project engineers attempt to resolve issues themselves because raising the problem increases the time to make a decision, which increases delays to the schedule. The project engineer enforces the contract to the highest standard because they take responsibility for the quality of the construction and are typically co-located with the end user. The resident engineers must maintain workloads to employ personnel. Reductions in the Department of Defense budget mean there will be less military construction projects and installations will conduct smaller projects to maintain their facilities with operation and maintenance funds. Customers have a choice when using these types of funds, unlike military construction funds, therefore the relationship between the local end user and resident office maintains primacy over keeping poor quality projects on schedule.

Change management concerns the project manager, but the direct interaction between the project engineer/contracting officer's representative and the contracting officer removes the project manager from most discussions regarding engineering changes. The project manager

${ }^{91}$ ER 1110-1-12, Quality Management (Washington, DC: US Army Corps of Engineers, 2011), 7-1; ER 1180-1-6, Construction Quality Management (Washington, DC: US Army Corps of Engineers, 1995), 7.

92 DFARS, Part 252 - Solicitation Provisions and Contract Clauses, Subpart 252.2 Text of Provisions and Clauses, Subpart 252.201-7000, accessed February 19, 2015, http://www.acq.osd.mil/dpap/dars/dfars/html/current/252201.htm. 
does not have the technical experience to provide an opinion on the situation and must rely on the construction and engineering branches. Project managers follow the USACE "change management process" for engineering changes, but it is more applicable to user requested changes. ${ }^{93}$

Customers change project requirements for any number of reasons including new personnel on the project with different visions of the product and input from end users. The customers work through the project managers to determine the effects of these changes, which results in additional coordination between the project engineer and the contractor to determine the impacts. Requests for additional or changes to the plan or schedule projections require a modification and increase cost growth. These changes can only occur if there are additional funds allocated to the project, determined by the project manager. ${ }^{94}$

The USACE Headquarters issued several documents in an attempt to control change. Engineer Regulation 1180-1-6 documents the involvement required by the construction personnel in contract award, design and construction phases of the project lifecycle. ${ }^{95}$ Engineer Regulation 1180-1-9 outlines how the organization executes design-build contracts. ${ }^{96}$ The Project Management Business Process Manual assigns the responsibility of contract oversight to the functional areas, while clearly stating the project manager leads the process. ${ }^{97}$ These separate regulations allow blame to pass between multiple organizations for project growth: the contractor for not following the contract, the construction branch for delayed reporting of contract

93 "Project Management Business Process Manual: Version 1.0", 64.

${ }^{94}$ Ibid.

${ }^{95}$ ER 1180-1-6, Construction Quality Management, 4.

${ }^{96}$ ER 1180-1-9, Design-Build Contracting (Washington, DC: US Army Corps of Engineers, 2012), 1

97 "Project Management Business Process Manual: Version 1.0", 59. 
disparities, contracting for accepting substandard work that requires modifications to meet standards at a later date, and project managers because they are the leaders. Every functional manager retains the ability to give their employee glowing evaluations because the employee put the functional manager's needs above the project. No one maintains ultimate responsibility when project cost growth occurs.

\section{US Army Engineer Brigade Project Construction}

The development of the bill of materials is the first step of the construction process that the construction management officer undertakes but it is not the last. This individual becomes the single point of contact to prevent project growth during construction, but he is still in the hierarchical self-contained technical headquarters section. The construction management officer develops the projects quality assurance requirements, is the point of contact from the brigade to maintain open communication between the customer and construction officer in charge, and tracks the progress of all the brigade projects to control construction cost growth. ${ }^{98}$

Quality assurance and quality control are two sides of the same coin. Quality control measurements evaluate the work done against the standard required, which the constructing unit does. ${ }^{99}$ Quality assurance evaluates the quality control program and performs random inspections of the work to ensure the constructing unit's quality control plan is effective. ${ }^{100}$ The quality assurance program provides oversight to ensure the project meets the previously defined scope of work without requiring the plans to change and cost to increase

98 "130th Engineer Brigade Construction Standard Operating Procedures", 14.

${ }^{99}$ Project Management Institute, A Guide to the Project Management Body of Knowledge: PMBOK® Guide, 244.

${ }^{100}$ Ibid., 242. 
The construction management officer works with individuals under his responsibility when developing the quality assurance plan. These four individuals have from two to twenty years of experience in the construction field. The brigade standard operating procedures also provide a format for developing the quality assurance plan to ensure inspectors examine the key aspects of the different types of project. ${ }^{101}$ Standardizing the way the brigades conduct quality assurance and assigning the oversight responsibility to one individual in the technical headquarters section ensures someone is accountable for the process.

In the event of the inevitable quality issues, maintaining open lines of communication between the individuals constructing the project and the customer reduces the impact of project growth. As the old adage says, bad news does not get better with age. Informing the customer of mistakes upfront allows them to evaluate the situation and determine if the problem needs corrected to the original design specification. The quality assurance team also informs the civil engineer to ensure the change does not require additional design work to correct the problem. Building code violations and safety concerns require correction and increase project cost. The construction management officer ensures all the required people know the quality issue and develops a consensus for the way forward. ${ }^{102}$

The final concern for managing construction growth is maintaining the schedule. The construction battalions control the workload of their soldiers, but the construction management officer consolidates the battalion's reports to ensure all the projects are complete. ${ }^{103}$ As projects begin to slip, the unit must allocate resources to get the project back on schedule. If a battalion

101 "130th Engineer Brigade Construction Standard Operating Procedures", 32; "555th Engineer Brigade "Willing and Able": Construction Standing Operating Procedures (CSOP) [Draft]", 13.

102 "130th Engineer Brigade Construction Standard Operating Procedures", 3; "555th Engineer Brigade "Willing and Able": Construction Standing Operating Procedures (CSOP) [Draft]", 12.

103 "130th Engineer Brigade Construction Standard Operating Procedures", 14. 
does not have additional soldiers to assign to the project, then they must request soldiers from the brigade. The task to perform "construction management for all projects within the Brigade" requires the construction management officer to know what resources are available if needed. ${ }^{104}$

The US Army does not experience increased labor costs by incorporating more soldiers because soldiers receive their pay as long as they serve "on active duty in a pay status". ${ }^{105}$ Furthermore, the law does not require soldiers to abide by the standard forty-hour workweek, which increases the options for correcting schedule overruns. These two differences with civilian construction mean that all cost overruns occurring from military construction projects are a direct result of improper planning or oversight, be it material costs or design changes.

Managing cost growth through the construction phase is difficult. The construction management officer must ensure there is a proper quality assurance plan in place to identify mistakes missed by the constructing unit's quality control personnel. He or she must inform the customer, civil engineer, and constructing unit's personnel of any mistakes that do occur in order to prevent the issue from causing project growth. Finally, the construction management officer must maintain resources in order to prevent the projects from running over schedule; upsetting the customer and causing lower morale when soldiers work late.

\section{Chapter 4 Conclusion}

The USACE districts' reliance on contracts allows project managers to see the construction as a single entity with the cost based solely on the contract. They fail to realize there are exponentially more coordination efforts that the contractor's project manager undertakes to complete the project. The linkages between the contractor and subordinate contractors increase

\footnotetext{
104 "130th Engineer Brigade Construction Standard Operating Procedures", 14.

${ }^{105}$ Army Regulation (AR) 37-104-4, Military Pay and Allowances Policy (Washington, DC: Government Printing Office, 2005), 4.
} 
the complexity of the project and introduce more points of failure. ${ }^{106}$ The contracting and construction branches focus on the detailed aspects of the contract and find situations that need resolved because of misunderstandings between the contractor and the wording of the contract. These resolutions cause construction project growth because the government will not allow contractors to do work without a modification. The matrix organization exacerbates the situation because the contracting officer and the project engineer report to their functional supervisors while enforcing the contract. Multiple regulations attempt to dictate the behavior during construction, but the regulations apply to different areas of the organization. Assigning one individual the responsibility of managing the personnel assigned to a project as well as the project outcome reduces the need for multiple and potentially conflicting regulations.

Army engineer brigades benefit from the oversight provided by the hierarchical structure. Commanders and staff at each level possess the ability to make decisions that directly affect the projects. The site manager works directly with the end user when issues occur and rapidly pushes problems up a single chain of command for resolution. The issue is resolved at the lowest level without the need to coordinate between multiple functional areas, reducing the number of interactions and simplifying the complexity. While USACE's project management business process sees the completion of the project as a single element with little interaction, Army engineer brigades ensure coordination using a single individual. The design engineer maintains open lines of communication with each organization, ensures the quality assurance personnel provide timely reports for the construction unit to use, and possesses a direct line of communication with the staff to coordinate additional assets when a project experiences schedule delays.

${ }^{106}$ Yaneer Bar-Yam, Making Things Work: Solving Complex Problems in a Complex World, ed. Chitra Ramalingam, Laurie Burlingame, and Cherry Ogata (United States: Knowledge Press, 2004), 24. 


\section{Conclusion}

The USACE districts' record for cost growth is over five percent for the past five years, while the Army engineer brigades conducting operations in the Pacific region have no project cost growth. US Army engineer brigades establish control by assigning a single person responsibility for an organization that ensures the project meets the organization's needs, designs the project specifications, manages the project's completion, and holds the individual accountable through evaluations for project overruns. The hierarchical structure ensures every person working on the project reports to a single manager without requirements from other managers. The USACE districts do not have a similar structure, and therefore cannot achieve the same success without improving their organization.

The USACE districts' organization resembles a "strong matrix", but where functional managers have the majority of authority. ${ }^{107}$ Matrix organizations can be effective, but project manager needs authority to control the employees and the organization must hold project managers accountable for overruns. ${ }^{108}$ The USACE project managers do not have evaluation responsibilities of the employees in the matrix, so the employees are more beholden to their functional managers. Conflicts require managerial decision making because the organization is highly diverse, but dependent on each functional branch. ${ }^{109}$ When employees do not agree with a project manager's decision, they appeal to their functional manager. If the functional and project managers disagree, the decision moves up the organizational stovepipes, leaving the senior management to resolve the conflict. These miscommunications, priority mismatches, and a lack of accountability lead to project growth.

\footnotetext{
${ }^{107}$ Project Management Institute, A Guide to the Project Management Body of Knowledge: PMBOK® Guide, 22.

${ }^{108}$ Mulcahy, $P M P{ }^{\circledR}$ Exam Prep, Rita et al., 22.

109 John P. Kotter, Power and Influence: Beyond Formal Authority (New York, NY: The Free Press, 1985), 19.
} 
Reorganizing the districts into self-contained units at regional offices and maintaining functional expertise at the district headquarters would provide the best opportunity to reduce miscommunication issues. Consolidating people in one location under the same boss reduces the diversity between employees, while assigning them under the direct control of a manager increases the interdependency. The decreased diversity and increased interdependency reduces the amount of conflict and prevents misunderstanding throughout the project process. ${ }^{110}$

The self-contained units could consist of a manager in a regional area with functional employees that only report to that manager. In small offices, the manager could maintain responsibility for project management while employees from engineering, construction, and resource management continue their responsibilities for that region. Larger offices may have a compliment of project managers, but the project managers would evaluate the functional employees and the regional managers would evaluate the project managers. These offices could have a deputy regional manager to relieve some of the workload of the regional manager. The districts could divide the regions into areas equivalent to the responsibility given to a lieutenant colonel, to maintain a reporting structure similar to that of an Army brigade.

Individuals from contracting and the legal department are a special case. Districts have a limited number of contracting officers; therefore, they use the resident and area engineers as administrative contracting officers. The regional manager could assume these duties, or the districts could increase the number of contracting officers. Regardless, each office should receive a contracting specialist to assist with preparing paperwork for the contracting officer. The plan results in a net loss of people, because the regional manager would assume the role of the project manager and resident engineer.

The reporting structure would flow from the regional managers directly to the district commander. The functional staff would remain at the district headquarters to provide guidance

${ }^{110}$ Kotter, Power and Influence: Beyond Formal Authority, 18. 
and advice to the district commander just as Army brigade staffs formulate plans for the brigade commander. The Deputy District Commander should assume a position equivalent to a brigade Executive Officer, which requires an increase in duties to include controlling the entire staff. The Deputy for Programs and Project Management assumes the role of the brigade Operations Officers. Program managers maintain their positions at the district office much like captains and majors in the brigade operations section. These individuals would maintain their contact with customers, receiving reports from the deputies of the regional offices and consolidating briefings to the commander. Such a structure would reduce the amount of interactions between organizations and localize personnel to prevent miscommunication. The commander would hold regional managers responsible for the actions in their regions, to include affecting their evaluations and continued service in the position.

The resulting organization would be a hybrid organization with functional employees at the district level and self-contained project offices at a regional level, similar to an Army engineer brigade with multiple technical headquarters sections. This organizational structure would decrease the number of managers and vertical integration levels. It would increase horizontal communication but limit the training of specialized employees. Ultimately, it would result in centralized accountability for project success or failure and ensure USACE commanders can evaluate subordinates based on their offices' performance, reducing project cost growth. While this proposal requires additional research to identify impacts and impediments to the organization, such changes promise to increase accountability of regional offices and increase opportunities to decrease project growth. 
Bibliography

"36th Engineer Brigade Construction SOP." Fort Hood, TX: 36th Engineer Brigade, 2013.

"130th Engineer Brigade Construction Standard Operating Procedures." Schofield Barracks, Hawaii: 130th Engineer Brigade, 2010.

"555th Engineer Brigade "Willing and Able": Construction Standing Operating Procedures (CSOP) [Draft]." Fort Lewis, WA: 555th Engineer Brigade, 2014.

Army Doctrinal Reference Publication (ADRP) 6-0. Mission Command. Washington, DC: Government Printing Office, 2012.

Army Regulation (AR) 37-104-4. Military Pay and Allowances Policy. Washington, DC: Government Printing Office, 2005.

AR 71-32. Force Development and Documentation. Washington, DC: Government Printing Office, 2013.

AR 210-20. Real Property Master Planning for Army Installations. Washington, DC: Government Printing Office, 2005.

AR 420-1. Army Facilities Management. Washington, DC: Government Printing Office, 2012.

Bar-Yam, Yaneer. Making Things Work: Solving Complex Problems in a Complex World. Edited by Chitra Ramalingam, Laurie Burlingame, and Cherry Ogata. United States: Knowledge Press, 2004.

Bordat, Claire, Bob G. McCullouch, Samuel Labi, and Kumares C. Sinha. "FHWA/IN/JTRP2004/7: An Analysis of Cost Overruns and Time Delays of INDOT Projects." West Lafayette, Indiana: Purdue University. Accessed February 11, 2015. http://docs.lib.purdue.edu/cgi/viewcontent.cgi?article=1482\&context=jtrp.

Carlisle, Howard M. Management: Concepts and Situations. United States of America: Science Research Associates, Inc., 1976.

Collins, Jim. Good to Great: Why Some Companies Make the Leap... and Others Don't. New York, NY: HarperCollins Publishers Inc., 2001.

"Command Management Review: 4QFY14." Washington, DC: Headquarters, US Army Corps of Engineers, 2014.

DesRoches, Paul. "Seeking Fundamental Issues: HQUSACE FY14 AAR, Nov 2014." Atlanta, GA: South Atlantic Division, 2014.

Engineer Pamphlet (EP) 360-1-21. The History of the US Army Corps of Engineers. Washington, DC: HQ, US Army Corps of Engineers, 1986.

Engineer Regulation (ER) 5-1-10. Corps-Wide Areas of Work Responsibility. Washington, DC: US Army Corps of Engineers, 2009. 
ER 5-1-11. USACE Business Process. Washington, DC: US Army Corps of Engineers, 2006.

ER 5-1-15. US Army Corps of Engineers Strategic Management. Washington, DC: US Army Corps of Engineers, 2009.

ER 1110-1-12. Quality Management. Washington, DC: US Army Corps of Engineers, 2011.

ER 1180-1-6. Construction Quality Management. Washington, DC: US Army Corps of Engineers, 1995.

ER 1180-1-9. Design-Build Contracting. Washington, DC: US Army Corps of Engineers, 2012.

Field Manual (FM) 5-34. Earthmoving Operations. Washington, DC: Government Printing Office, 2000.

FM 5-164. Tactical Land Clearing. Washington, DC: Government Printing Office, 1974. Accessed December 11, 2014.

http://www.globalsecurity.org/jhtml/jframe.html\#http://www.globalsecurity.org/military/l ibrary/policy/army/fm/5-434/toc.pdf.

Grathwol, Robert P. and Donita M. Moorhus. Bricks, Sand, and Marble: US Army Corps of Engineers Construction in the Mediterranean and Middle East, 1947-1991. Washington, DC: Government Printing Office, 1992.

Jenner, Kriten. "Changes Coming to the Engineer Officer Career Field." Accessed February 13, 2015. http://usaes.armylive.dodlive.mil/2012/01/20/changes-coming-to-the-engineerofficer-career-field/ posted January 20, 2012, 7:26 pm.

Jones, Gareth R. and Jennifer M. George. Contemporary Management. 5th ed. St. Louis, IL: McGraw-Hill/Irwin, 2008.

Kerzner, Harold. PM Best Practices. 2nd ed. New York, NY: International Institute for Learning, 2010.

Kotter, John P. Power and Influence: Beyond Formal Authority. New York, NY: The Free Press, 1985.

Lawson, Bryan. How Designers Think: The Design Process Demystified. 4th ed. New York, NY: Elsevier Ltd., 2006.

Maurer, John G. foreword to Organization Charts: Structures of more than 200 businesses and non-profit organizations. Edited by Judith M. Nixon. Detroit, MI: Gale Research Inc., 1992.

Morgan, Gareth. Images of Organization. Thousand Oaks, CA: SAGE Publications, Inc., 1997.

Mulcahy, Rita et al. PMP® Exam Prep, 8th ed. Minneapolis, MN: RMC Publishing, 2013.

Procurement Instruction Letter (PIL) 2012-06-R1. US Army Corps of Engineers (USACE) Policy for Certification and Training of Contracting Officer's Representatives. Washington, DC: US Army Corps of Engineers, 2012. 
"Project Management Business Process Manual: Version 1.0." Washington, DC: US Army Corps of Engineers, 2009.

Project Management Institute. A Guide to the Project Management Body of Knowledge: PMBOK ${ }^{\circledR}$ Guide. 5th ed. Newton Square, PA: Project Management Institute, Inc., 2013.

—_. "Project Management Professional (PMP) ${ }^{\circledR}$." Project Management Professional Certification. Accessed October 16, 2014. http://www.pmi.org/Certification/ProjectManagement-Professional-PMP.aspx.

"RMS User's Guide: Software Version 2.38." Los Angeles, CA: RMS Center, Los Angeles District, US Army Corps of Engineers, 2012. Accessed February 8, 2014. http://rms.usace.army.mil/datafiles/RMS_QCS_Manuals/rms_manual_2_38.pdf.

Shrestha, Pramen P., Leslie A. Burns and David R. Shields. "Magnitude of Construction Cost and Schedule Overruns in Public Works Projects." Edited by Manoj Jha. Journal of Construction Engineering Volume 2013 (October 2013): Article ID 935978. Accessed February 11, 2015. http://www.hindawi.com/journals/jcen/2013/935978/.

"Solicitation, Offer, and Award, W912GB-15-R-0008." Wiesbaden, Germany: US Army Corps of Engineer, Europe District, 2015. Accessed February 15, 2015. https://acquisition.army.mil/asfi/sol_attachment_viewer.cfm?psolicitationnbr=W912GB1 5R0008\&FILE_NAME=C\%2D05\%5FW912GB\%2D15\%2DR\%2D0008\%5FTurkeyMA TOCSol\%2Epdf\&ext= (.pdf)\&isXML=N.

"Solicitation, Offer, and Award, W912DY-15-T-0031." Huntsville, AL: Huntsville Engineering \& Support Center. Accessed February 15, 2015. https://acquisition.army.mil/asfi/attachment_viewer.cfm?Sol_Number=W912DY15T003 1\&Seq_Nbr=510651\&FILE_NAME=W912DY15T0031.pdf\&FILE_EXTENSION=pdf.

Training Manual (TM) 3-34.62. Earthmoving Operations. Washington, DC: Government Printing Office, 2012. Accessed December 11, 2014.

https://armypubs.us.army.mil/doctrine/DR_pubs/dr_aa/pdf/tm3_34x62.pdf.

Turgot, Anne Robert Jacques. Observation sur un Mémoire de M. de Saint-Péravy (1767). In Euvres de Turgot et Documents le Concernant. vol. 2. Edited by Gustave Schelle. Paris: Librairie Felix Alcan, 1914, 644. Quoted in Stanley Brue and Randy Grant, The Evolution of Economic Thought. 8th ed. Mason, OH: South-Western Cengage Learning, 2007.

Unified Facilities Criteria (UFC) 1-300-07a. Design Build Technical Requirements. Washington, DC: US Army Corps of Engineers, 2005.

USACE p2v3. "P2 Execution Overview." In "USACE P2 Overview Movies" (video). Posted April 3, 2013. Accessed February 19, 2015. https://www.youtube.com/watch?v=rZwwUV0D3kA\&list=PL459657E7965482F4.

US Army Corps of Engineers. "US Army Corps of Engineers Locations." Accessed December 11, 2014. http://www.usace.army.mil/Locations.aspx. 
US Army Corps of Engineers, Europe District. "US Army Corps of Engineers, Europe District, Locations, District Offices." Accessed on October 16, 2014.

http://www.nau.usace.army.mil/Locations/DistrictOffices.aspx.

US Army Corps of Engineers, Far East District. "US Army Corps of Engineers, Far East District, Locations, Resident and Area Offices." Accessed on October 16, 2014.

http://www.pof.usace.army.mil/Locations/ResidentandAreaOffices.aspx

US Army Corps of Engineers, Omaha District. "US Army Corps of Engineers, Omaha District, Location, District Locations." Accessed on October 16, 2014.

http://www.nwo.usace.army.mil/Locations.aspx

US Army Corps of Engineers, St. Paul District. "US Army Corps of Engineers, St. Paul District, Locations, District Maps and Locations." Accessed on October 16, 2014.

http://www.mvp.usace.army.mil/Locations/DistrictMapsLocations.aspx.

US Army Force Management Support Agency. "20th Engineer Brigade MTOE.” FMSWeb Force Management Database. Accessed December 9, 2014.

https://fmsweb.army.mil/protected/WebTAADS/UIC_Frame.asp?DOC_TYPE=MTOE\& Update $=$ GETSQL $\&$ MACOM $=$ FC $\& D O C N O=05402 R F C 18 \& C C N U M=0116 \& D O C S T=$ A\&UIC=WGENAA\&EDATE=10/16/2015.

—_. "36th Engineer Brigade MTOE." FMSWeb Force Management Database. Accessed December 9, 2014.

https://fmsweb.army.mil/protected/WebTAADS/UIC_Frame.asp?DOC_TYPE=MTOE\& Update $=$ GETSQL $\& M A C O M=F C \& D O C N O=05402 R F C 02 \& C C N U M=0116 \& D O C S T=$ A\&UIC=WAZQAA\&EDATE=10/16/2015.

. "130th Engineer Brigade MTOE.” FMSWeb Force Management Database. Accessed December 9, 2014.

https://fmsweb.army.mil/protected/WebTAADS/UIC_Frame.asp?DOC_TYPE=MTOE\& Update $=\mathrm{GETSQL} \& \mathrm{MACOM}=\mathrm{P} 1 \& D O C N O=05402 \mathrm{RP} 113 \& C C N U M=0116 \& D O C S T=$ A\&UIC=WHDLAA\&EDATE=10/16/2015.

—_. "555th Engineer Brigade MTOE." FMSWeb Force Management Database. Accessed December 9, 2014.

https://fmsweb.army.mil/protected/WebTAADS/UIC_Frame.asp?DOC_TYPE=MTOE\& Update $=$ GETSQL $\& M A C O M=F C \& D O C N O=05402 R F C 17 \& C C N U M=0116 \& D O C S T=$ A\&UIC=WAZTAA\&EDATE $=10 / 16 / 2015$.

_ . "2015 Engineer Division Great Lakes and Ohio River TDA.” FMSWeb Force Management Database. Accessed December 11, 2014.

https://fmsweb.army.mil/protected/WebTAADS/UIC_Frame.asp?DOC_TYPE=TDA\&U pdate $=\mathrm{GETSQL} \& \mathrm{MACOM}=\mathrm{CE} \& D O C N O=\mathrm{CEW} 072 \mathrm{AA} \& \mathrm{CCNUM}=0216 \& D O C S T=\mathrm{A}$ $\& U I C=W 072 A A \& E D A T E=10 / 2 / 2015$.

—_. "2015 Engineer Division Northwestern TDA.” FMSWeb Force Management Database. Accessed December 11, 2014.

https://fmsweb.army.mil/protected/WebTAADS/UIC_Frame.asp?DOC_TYPE=TDA\&U pdate $=$ GETSQL $\& M A C O M=C E \& D O C N O=C E W 071 \mathrm{AA} \& C C N U M=0116 \& D O C S T=A$ $\& U I C=W 071 A A \& E D A T E=10 / 1 / 2015$. 
_ _ "2015 Engineer Division Southwestern TDA.” FMSWeb Force Management Database. Accessed December 11, 2014. https://fmsweb.army.mil/protected/WebTAADS/UIC_Frame.asp?DOC_TYPE=TDA\&U pdate $=$ GETSQL \&MACOM $=\mathrm{CE} \& D O C N O=C E W 076 \mathrm{AA} \& C C N U M=0116 \& D O C S T=A$ $\& U I C=W 076 A A \& E D A T E=10 / 1 / 2015$.

_ _ "2015 Engineer Division Transatlantic TDA.” FMSWeb Force Management Database. Accessed December 11, 2014. https://fmsweb.army.mil/protected/WebTAADS/UIC_Frame.asp?DOC_TYPE=TDA\&U pdate $=$ GETSQL\&MACOM $=$ CE $\& D O C N O=C E W 31$ RAA $\& C C N U M=0116 \& D O C S T=A$ \&UIC=W31RAA\&EDATE $=10 / 1 / 2015$.

—_ “2015 Mississippi Valley Division TDA.” FMSWeb Force Management Database. Accessed December 11, 2014. https://fmsweb.army.mil/protected/WebTAADS/UIC_Frame.asp?DOC_TYPE=TDA\&U pdate $=$ GETSQL \&MACOM $=\mathrm{CE} \& D O C N O=C E W 07 V A A \& C C N U M=0116 \& D O C S T=A$ $\& U I C=W 07 V A A \& E D A T E=10 / 1 / 2015$.

"2015 North Atlantic Division TDA.” FMSWeb Force Management Database. Accessed December 11, 2014. https://fmsweb.army.mil/protected/WebTAADS/UIC_Frame.asp?DOC_TYPE=TDA\&U pdate $=\mathrm{GETSQL} \& M A C O M=\mathrm{CE} \& D O C N O=\mathrm{CEW} 2 \mathrm{SDAA} \& \mathrm{CCNUM}=0116 \& D O C S T=\mathrm{A}$ $\& U I C=W 2 S D A A \& E D A T E=10 / 1 / 2015$.

. "2015 Pacific Ocean Division TDA." FMSWeb Force Management Database. Accessed December 11, 2014. https://fmsweb.army.mil/protected/WebTAADS/UIC_Frame.asp?DOC_TYPE=TDA\&U pdate $=\mathrm{GETSQL} \& \mathrm{MACOM}=\mathrm{CE} \& \mathrm{DOCNO}=\mathrm{CEW} 2 \mathrm{SNAA} \& \mathrm{CCNUM}=0216 \& D O C S T=\mathrm{A}$ $\& U I C=W 2 S N A A \& E D A T E=10 / 2 / 2015$.

. "2015 South Atlantic Division TDA.” FMSWeb Force Management Database. Accessed December 11, 2014. https://fmsweb.army.mil/protected/WebTAADS/UIC_Frame.asp?DOC_TYPE=TDA\&U pdate $=\mathrm{GETSQL} \& M A C O M=\mathrm{CE} \& D O C N O=\mathrm{CEW} 074 \mathrm{AA} \& \mathrm{CCNUM}=0116 \& D O C S T=\mathrm{A}$ $\& U I C=W 074 A A \& E D A T E=10 / 1 / 2015$.

—_. "2015 South Pacific Division TDA.” FMSWeb Force Management Database. Accessed December 11, 2014.

https://fmsweb.army.mil/protected/WebTAADS/UIC_Frame.asp?DOC_TYPE=TDA\&U pdate $=$ GETSQL $\& M A C O M=C E \& D O C N O=C E W 075 A A \& C C N U M=0116 \& D O C S T=A$ $\& U I C=W 075 A A \& E D A T E=10 / 1 / 2015$.

US Army Geospatial Center. "Oversees Humanitarian Assistance Shared Information System (OHASIS)." Accessed December 9, 2015. https://www.ohasis.org.

US Office of Management and Budget. FY2015 Budget of the US Government. Washington, DC: US Government Printing Office, 2014. Accessed August 20, 2014. http://www.whitehouse.gov/sites/default/files/omb/budget/fy2015/assets/budget.pdf.

Wolf, Ulf. "The Change Order: Blessing or Curse?" Construction Dimensions: Published for Contractors by the Association of the Wall and Ceiling Industry (January 2014). Accessed February 15, 2015. http://www.awci.org/cd/showArticle.pl?id=1515. 